\title{
Mercury in Sediment Core Samples From Deep Siberian Ice-Rich Permafrost
}

\begin{abstract}
Clara Rutkowski ${ }^{1,2}$, Josefine Lenz ${ }^{1,3}$, Andreas Lang ${ }^{2}$, Juliane Wolter ${ }^{1,4}$, Sibylle Mothes ${ }^{5}$, Thorsten Reemtsma ${ }^{5}$, Guido Grosse ${ }^{1,6}$, Mathias Ulrich ${ }^{7}$, Matthias Fuchs ${ }^{1}$, Lutz Schirrmeister $^{1}$, Alexander Fedorov ${ }^{8}$, Mikhail Grigoriev ${ }^{9}$, Hugues Lantuit ${ }^{1,6}$ and Jens Strauss ${ }^{1 *}$

${ }^{1}$ Permafrost Research Section, Alfred Wegener Institute Helmholtz-Centre for Polar and Marine Research, Potsdam, Germany, ${ }^{2}$ Department of Geography and Geology, Paris Lodron University Salzburg, Salzburg, Austria, ${ }^{3}$ Water and Environmental Research Center, Institute of Northern Engineering, University of Alaska Fairbanks, Fairbanks, AK, United States, ${ }^{4}$ Institute of Biochemistry and Biology University of Potsdam, Potsdam, Germany, ${ }^{5}$ Department of Analytical Chemistry, Helmholtz-Centre for Environmental Research-UFZ, Leipzig, Germany, ${ }^{6}$ Institute of Geosciences, University of Potsdam, Potsdam, Germany, ${ }^{7}$ Institute for Geography, Leipzig University, Leipzig, Germany, ${ }^{8}$ Laboratory of Permafrost Landscapes, Melnikov Permafrost Institute Siberian Branch of the Russian Academy of Sciences, Yakutsk, Russia, ${ }^{9}$ Laboratory of General Geocryology, Melnikov Permafrost Institute Siberian Branch of the Russian Academy of Sciences, Yakutsk, Russia
\end{abstract}

\section{OPEN ACCESS}

Edited by:

Timothy Ferdelman,

Max Planck Institute for Marine Microbiology (MPG), Germany

Reviewed by:

Tetsuo Sueyoshi,

National Institute of Polar Research,

Japan

Kyra St.Pierre,

University of British Columbia, Canada

*Correspondence:

Jens Strauss

jens.strauss@awi.de

Specialty section:

This article was submitted to Biogeoscience,

a section of the journal

Frontiers in Earth Science

Received: 31 May 2021

Accepted: 13 August 2021 Published: 03 September 2021

Citation:

Rutkowski C, Lenz J, Lang A, Wolter J, Mothes S, Reemtsma T, Grosse G, Ulrich M, Fuchs M, Schirrmeister L, Fedorov A, Grigoriev M, Lantuit H and Strauss J (2021) Mercury in Sediment Core Samples From Deep Siberian IceRich Permafrost. Front. Earth Sci. 9:718153. doi: 10.3389/feart.2021.718153
We determine Hg concentrations of various deposits in Siberia's deep permafrost and link sediment properties and $\mathrm{Hg}$ enrichment to establish a first $\mathrm{Hg}$ inventory of late Pleistocene permafrost down to a depth of $36 \mathrm{~m}$ below surface. As Arctic warming is transforming the icerich permafrost of Siberia, sediment is released and increases the flux of particulates to the Arctic shelf seas through thawing coasts, lakeshores, and river floodplains. Heavy metals within soils and sediments are also released and may increasingly enter Arctic waters and the biological food chain. High levels of mercury $(\mathrm{Hg})$ have been reported from shallow soils across the Arctic. Rapid thawing is now mobilizing sediment from deeper strata, but so far little is known about Hg concentrations in deep permafrost. Here, forty-one samples from sediment successions at seven sites and of different states of permafrost degradation on Bykovsky Peninsula (northern Yakutian coast) and in the Yukechi Alas region (Central Yakutia) were analyzed for Hg, total carbon, total nitrogen, and total organic carbon as well as grain-size distribution, bulk density, and mass specific magnetic susceptibility. We show average Hg concentrations of $9.72 \pm$ $9.28 \mathrm{mg} \mathrm{kg}^{-1}$ in the deep sediments, an amount comparable to the few previous Arctic studies existing, and a significant correlation of $\mathrm{Hg}$ content with total organic carbon, total nitrogen, grain-size distribution, and mass specific magnetic susceptibility. Hg concentrations are higher in the generally sandier sediments of the Bykovsky Peninsula than in the siltier sediments of the Yukechi Alas. The ratio of $\mathrm{Hg}$ to total organic carbon in this study is $2.57 \mathrm{~g} \mathrm{~kg}^{-1}$, including samples with very low carbon content. We conclude that many deep permafrost sediments, some of which have been frozen for millennia, contain elevated concentrations of $\mathrm{Hg}$ and the stock of $\mathrm{Hg}$ ready to be released by erosion is of significance for the Arctic ecosystem. The Hg mobilized may accumulate on the way to or in the shallow sea, and where it enters into active biogeochemical cycles of aquatic systems it may concentrate in food webs. Our study highlights the need for better understanding $\mathrm{Hg}$ stocks and $\mathrm{Hg}$ release from permafrost.

Keywords: arctic, pollutants, heavy metal, arctic warming, polar regions 


\section{INTRODUCTION}

Climate change and thus environmental transitions have an enormous impact on polar regions (Schuur et al., 2008; Jones et al., 2020) and their local populations (Ramage et al., 2021). This study focuses on a very sensitive part of the terrestrial Arctic: Ice-bearing deposits in Yedoma permafrost landscapes, tens of meters thick. Yedoma landscapes are characterized mostly by fine sandy to silty, ice-rich deposits of late Pleistocene age. They occur in areas that were not glaciated during the last ice ages and accumulated sediments for thousands of years (Kostyukevich, 1993; Grosse et al., 2013; Strauss et al., 2013). Syngenetic ice wedges and intrasedimentary ice are characteristic for Yedoma deposits (Grosse et al., 2013). The frozen sediment layers have preserved organic matter (OM) and associated contaminants, generally acting as an organic carbon (OC) sink (Lindgren et al., 2018; Walz et al., 2018).

Since the late 1970 s, permafrost temperatures have increased between 0.5 and $2^{\circ} \mathrm{C}$ worldwide (Larsen et al., 2014; Biskaborn et al., 2019); the deep and ice-rich Yedoma permafrost from the late Pleistocene is suggested as a major source of greenhouse gas emission when it thaws (Schuur et al., 2015; Strauss et al., 2017). Besides climate relevant substances such as methane and carbon dioxide, other freeze-locked elements and compounds will also be released as permafrost degrades. Among these are nutrients (Beermann et al., 2015) but also harmful contaminants, such as heavy metals, including mercury ( $\mathrm{Hg})$.

$\mathrm{Hg}$ is a natural element of the lithosphere and its primary mechanism of mobilization and release to the environment is through volcanism, as well as via weathering and erosion of continental rock (Streets et al., 2011). Its distribution through the atmosphere and hydrosphere also allows its uptake in ecosystems. Such $\mathrm{Hg}$ can then be re-emitted (secondary emission) via soil respiration, biomass incineration, and oceans (gas exchange or as aerosolized droplets from sea spray-wind interaction) (Driscoll et al., 2013). Anthropogenic sources are more diverse but they have augmented the hemisphere-wide natural flux immensely (Pirrone et al., 2009; Streets et al., 2011) and $\mathrm{Hg}$ concentration in atmospheric deposition has increased threefold since industrialization (Driscoll et al., 2013). Hg deposition is usually in the form of inorganic $\mathrm{Hg}^{2+}$ complexes (Schroeder and Munthe, 1998; Xin et al., 2007). When Hg binds to $\mathrm{OC}$, it is incorporated into the carbon cycle and can travel among several carbon pools. The storage of $\mathrm{Hg}$ in $\mathrm{OC}$ has increased by approximately $20 \%$ since pre-industrial times (Smith-Downey et al., 2010). Especially the Arctic tundra and its uptake of gaseous $\mathrm{Hg}^{0}$ during summer months is suggested to be a globally important $\mathrm{Hg}$ sink (Obrist et al., 2017). The role of plants in the accumulation of atmospheric $\mathrm{Hg}$ in permafrost soils has been stressed in a number of recent studies (Jiskra et al., 2019; Obrist et al., 2017; Olson et al., 2019). Non-vascular plants such as mosses and lichens have been shown to take up large amounts of atmospheric $\mathrm{Hg}$ (Olson et al., 2019). This looks to be one major explanation for the elevated $\mathrm{Hg}$ concentrations found in permafrost soils as compared with soils from lower latitudes (non-permafrost soils). The accumulation of $\mathrm{Hg}$ in permafrost soils has occured over the course of millennia (Obrist et al., 2017).

Organomercury compounds are liposoluble and penetrate biological membranes easily (Carneado et al., 2015). The most hazardous and neurotoxic form of organomercury is methylated $\mathrm{Hg}\left(\mathrm{MeHg}\right.$ ) (Schroeder and Munthe, 1998), in particular $\mathrm{CH}_{3} \mathrm{Hg}^{+}$ (monomethylmercury). The methylation process is mainly driven by bacteria (biogenic) and occurs generally under reducing conditions that usually occur in wetlands, waterlogged sediments, coastal shallow water zones, and upper ocean layers (Driscoll et al., 2013). Water-saturated unfrozen soils in the Arctic permafrost region offer similar conditions. The increasing disposability of nutrients and the rise of microbial activities in thawing permafrost therefore lead to augmented methylation of the available $\mathrm{Hg}$, particularly in water surroundings (MacMillan et al., 2015; St. Pierre et al., 2018). In light of the high toxicity of organomercury compounds ( $\mathrm{Ha}$ et al., 2017) there is a need for improving our understanding of $\mathrm{Hg}$ pools to help constrain the hazard potential to human health posed by $\mathrm{Hg}$ liberation through arctic climate change.

Other studies (Burke et al., 2017; Obrist et al., 2017; Schuster et al., 2018) highlight the importance of elevated $\mathrm{Hg}$ concentrations in Arctic soils and thermokarst lake sediments, but to date insufficient data are available for the Russian Arctic (Lim et al., 2020), especially for deep deposits of the Yedoma landscape which degrades with ongoing climate warming. Current estimates of potential $\mathrm{Hg}$ release with ongoing permafrost thaw are based almost entirely on data from shallow (top one to three $\mathrm{m}$ ) sediments (e.g., Schuster et al., 2018; Lim et al., 2020; Schaefer et al., 2020) but climate driven transformation processes in Yedoma regions affect also deeper sediment layers (Schirrmeister et al., 2020).

Our study aims to estimate $\mathrm{Hg}$ quantities in deep permafrost from a Yedoma-dominated landscape. The objective of this paper is a first examination of $\mathrm{Hg}$ at depth to enable a rough risk assessment in terms of future $\mathrm{Hg}$ release to Arctic ecosystems. We determine $\mathrm{Hg}$ in seven deep cores from two Siberian permafrost regions: 1) the Bykovsky Peninsula southeast of the Lena Delta near the city of Tiksi, and 2) the Yukechi Alas, $50 \mathrm{~km}$ southeast of the city of Yakutsk. Our set of cores includes permafrost at different stages of degradation, from varying sedimentary origins, and with differing periglacial properties. We explore: 1) if $\mathrm{Hg}$ concentrations in deep permafrost soils of Yedoma landscapes differ from those of shallow levels, and 2) to what extent permafrost landscape features (late Pleistocene permafrost vs. Holocene permafrost, lake or lagoon deposits vs. dry Alas or Yedoma deposits) show distinct $\mathrm{Hg}$ patterns.

\section{STUDY AREA}

To enable comparison of different states of permafrost degradation in Holocene and late Pleistocene $\left(10^{4}-10^{5}\right.$ years old) deposits, two study sites on the Lena River in Siberia, Russia were chosen (Figure 1A): the Bykovsky Peninsula to 


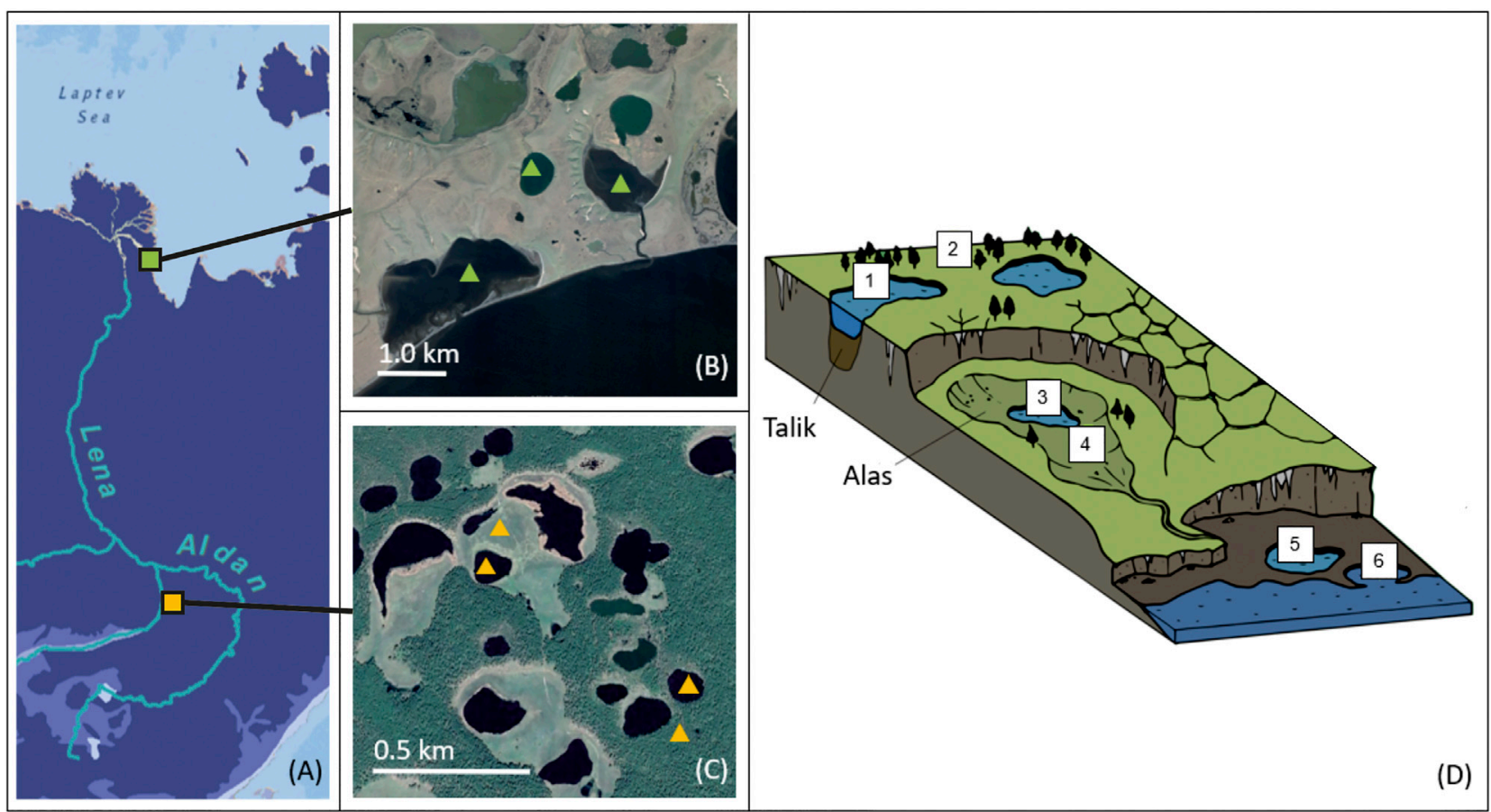

FIGURE 1 |Drilling location overview (A) and details of the study sites at Bykovsky Peninsula (B) and the Yukechi Alas in Yakutia (C); environmental sketch of study sites and different states of permafrost degradation in Siberia (D). The numbers indicate: 1) Yedoma upland: unfrozen zone in Yedoma permafrost (talik), 2) late Pleistocene Yedoma (frozen), 3) Alas basin: talik below thermokarst lake (unfrozen), 4) drained lake basin, 5) Thermokarst setting: talik below thermokarst lake (unfrozen), 6) lagoonal setting: talik below seawater-flooded thermokarst basins (unfrozen). The triangle symbols in Figures $\mathbf{1 B}, \mathbf{C}$ indicate the location of the single drilling sites in the orthophotos.

the north (Figure 1B) and the Yukechi Alas about $1,000 \mathrm{~km}$ further south (Figure 1C). Within each site, sediment cores from different permafrost landscape elements were selected and sampled (see also Supplementary Figure A).

\section{Yukechi Alas}

The Yukechi Alas is located within the zone of continuous permafrost and about $50 \mathrm{~km}$ southeast of Yakutsk, the capital of the Sakha Republic (Yakutia). The region of Central Yakutia is dominated by alluvial and lacustrine accumulation on the right bank of the Lena River (Figure 1A) (Soloviev, 1973). Large parts of the Central Yakutian lowland remained unglaciated during the late Pleistocene, allowing aggradation of massive silty and sandy deposits under cold conditions, forming Yedoma. Today, large syngenetic ice wedges up to $50-60 \mathrm{~m}$ in height underlie between 30 and $60 \%$ of the massive alluvial terraces (Kostyukevich, 1993; Brouchkov et al., 2004). Alas landscapes appear as result of thermokarst processes, where ground ice or frozen soil thaws extensively. This leads to permafrost degradation and surface deformation since the Holocene (Soloviev, 1973). Part (D) of Figure 1 shows some typical thermokarst landforms in Central Yakutia: Alas lakes (3) and drained Alas basins (4), surrounded by the older Yedoma landscape of mid to late Pleistocene age (2). The Yedoma landscape at the Yukechi study site also contains lakes, sometimes with thawed talik layers below (1) and vertical soil displacements caused by melting ice wedges (not numbered). The Lena River and shallow thermokarst lakes are the most important water sources for the local population because permafrost inhibits upwelling of ground water (Fedorov and Konstantinov, 2003). The Lena River and its tributaries are also the main sediment supplier of this area. The study site is at $200-220 \mathrm{~m}$ above sea level (a.s.l.) and local relief between Yedoma upland surfaces and the Yukechi Alas basin floors is 10-15 m. Several Alas generations with a depth of 8-10 m occur and are dominated by thermokarst lakes and flat plains (see Supplementary Figure B(A)). New lakes and depressions develop continuously as a result of active thermokarst processes (Fedorov and Konstantinov, 2003). Newly formed taliks (perennially unfrozen areas in the permafrost realm) below young thermokarst lakes in Yedoma uplands (Fedorov et al., 2014; Ulrich et al., 2017; Ulrich et al., 2019) are also indicative of ongoing thaw processes.

The Yukechi Alas is situated within the taiga biome with larch forests interspersed with pine and birch, a well-developed shrub layer (willows, alder, rose, various Ericaceae) and often welldeveloped moss layers dominating on Yedoma uplands. The studied alas itself has azonal grassland vegetation, in which non-vascular plants (mosses, lichens) play a minor role, except along the shores and in shallow parts of alas lakes. The regional vegetation has been influenced by anthropogenic clearing of 
forest and use of alas grasslands for pasture and agriculture during the 20th century (Crate et al., 2017) and a high natural fire frequency throughout the Holocene (Katamura et al., 2009). The current larch and pine forests and surface fire regime have been present in the region for at least 6,500 years (Katamura et al., 2009), and alas depressions have started to develop around the same time (Ulrich et al., 2017).

\section{Bykovsky Peninsula}

The Bykovsky Peninsula is located southeast of the Lena River Delta (Northern Yakutia). This area is also characterized by widespread Yedoma and thermokarst landscapes. The latter include brackish lakes close to the seashore and lagoons (Figure 1(D5,D6)). The peninsula is elongated in the NNWSSE direction, is part of a late Pleistocene coastal plain, and represents a typical setting for the coastal lowlands of the Laptev Sea (Grosse et al., 2005). The local topography of the peninsula varies from $0 \mathrm{~m}$ up to $45 \mathrm{~m}$ a.s.l. (Schirrmeister et al., 2018) and the total length of the shoreline is about $150 \mathrm{~km}$. Cliffs and lowlying thermokarst basins are the typical backshore coastal landforms. Thermokarst basins resulting from thawing of icerich permafrost cover about $46 \%$ of the peninsula (Grosse et al., 2005) and will prospectively transform into lakes and lagoons (see Supplementary Figure $\mathbf{B}(\mathbf{B})$ ). Within the basins, ice-wedge polygonal structures can easily be detected from remote sensing imagery (Grosse et al., 2005; Schneider et al., 2009; Strauss et al., 2018). Some cliffs are relatively stable and covered by vegetation; others are near vertical, reaching tens of meters in height, and often expose large syngenetic ice wedges and ice-rich Yedoma deposits. In general, the deposits of the Bykovsky Peninsula are poorly sorted sandy silt (Schirrmeister et al., 2002; Strauss et al., 2018; Schirrmeister et al., 2020) with frequent intercalations of peat and paleosols (Lantuit et al., 2011). Many retrogressive thaw slumps and thermokarst basins indicate the degraded state of the permafrost (see Supplementary Figure $\mathbf{B}(\mathbf{C})$ ). Subaquatic permafrost exists on and around the peninsula and undergoes complex thaw processes (Overduin et al., 2016). Recent transitions from thermokarst lakes to lagoons in this area and consequent talik dynamics are described by Angelopoulos et al. (2020).

This study site is situated in the tundra biome, with dwarf shrubs, sedges, grasses, and herbs growing above a well-developed moss layer. Lichens are present, but usually do not have a high cover. In contrast to the region around Yukechi Alas, the regional vegetation on Bykovsky Peninsula has not been subjected to anthropogenic land use and has been less impacted by fires throughout the Holocene (Nitze et al., 2018).

\section{MATERIALS AND METHODS}

\section{Sediment Cores and Subsampling}

For this study, we investigated sediment cores from each of the landscape elements that are numbered in Figure 1D to gain insight into different permafrost degradation states. Winter fieldwork in the Yukechi Alas was conducted in March 2015. We drilled four sediment cores with a drilling rig (Geotechnika
URB 4T) from lake ice or ground surface to depths between 19.80 and $22.35 \mathrm{~m}$. For $\mathrm{Hg}$ analyses, we took five to seven subsamples from each core (Table 1). The YU-L7 sediment core (total length: $17.7 \mathrm{~m}$ ) derives from a small residual Alas lake located within the Yukechi Alas basin (Figure 1(D3)). Here, we took five subsamples. Depth is given as depth below surface and includes lake depth. The sediment core starts at $2.30 \mathrm{~m}$ below the lake-ice surface (b.l.s.). Another five subsamples were taken from the YU-L15 sediment core (total length: $17.06 \mathrm{~m}$ ) beneath a young thermokarst lake on late Pleistocene Yedoma deposits (Figure 1(D1)). The top of the sediment is at $4.40 \mathrm{mb}$ b.l.s. At $22.35 \mathrm{~m}$ YED-1 is the longest of all Central Yakutian cores. We drilled into the dry Yedoma surface surrounding the Yukechi Alas (Figure 1(D2)) and investigated seven subsamples of this core. The ALAS-1 sediment core came from the dry bottom of the Yukechi Alas center (Figure 1(D4)). This core has a total length of $19.80 \mathrm{~m}$ and five subsamples were taken. Except for YED-1, some core loss occurred in all cores where unfrozen sediment was encountered; e.g. in ALAS-1, material was lost in the upper part between 2.25 and $9.34 \mathrm{~m}$ below surface (b.s.). Detailed stratigraphic descriptions of the YU-L7 and YU-L15 cores are available in Jongejans et al. (2021); Ulrich et al. (2021). Detailed stratigraphic descriptions of the terrestrial cores can be found in Windirsch et al. (2020).

In April 2017, we drilled three 27.45-32.30 m long cores on Bykovsky Peninsula with an URB 4T drilling rig. Two of the cores originate from thermokarst lagoons (Figure 1(D6)), while the third originates from a thermokarst lake (Figure 1(D5)) (Strauss et al., 2018). PG2410 contains sediment from below the $1.20 \mathrm{~m}$ deep Uomullyakh-Kyuel Lagoon and is $32.30 \mathrm{~m}$ long. Here, we analyzed seven subsamples. PG2411, a sediment core from below the $3.30 \mathrm{~m}$ deep Polar Fox Lagoon, has a total length of $27.45 \mathrm{~m}$ and we took six subsamples. Uomullyakh-Kyuel Lagoon is a former thermokarst lake and due to coastal erosion is now part of the coastline. Polar Fox Lagoon is a partially drained thermokarst lake close to the coastline. A channel has developed allowing exchange with sea water (Angelopoulos et al., 2020). The third north Yakutian core, PG2412, is the longest of all cores and it comes from the thermokarst lake Goltsovoye. Its total length is $31.55 \mathrm{~m}$ and it starts at a depth of $5.10 \mathrm{mb}$ b.l.s. We also investigated six subsamples of this core. Figure $\mathbf{2}$ gives another schematic overview of all seven core locations, complemental to Figure 1.

The cores were cryolithologically described in the field, wrapped in foil, and stored frozen in thermo-boxes. We kept all core material frozen during transport and storage and cores were sampled at a temperature of $-10^{\circ} \mathrm{C}$ in the cold chamber in Potsdam. We cut the cores in half using a band saw and cleaned, photographed, described, and sampled them approximately every $3 \mathrm{~m}$ except where no material was available or visible stratigraphic changes occurred. Sediment columns of 5-10 cm thickness were sampled for analyses and the center depth of each column is given as sample depth. To avoid contamination, nitrile gloves were used during subsampling and the outermost few millimeters of the sediment columns sampled were removed using a ceramic knife. The samples were stored in plastic sample bags, covered with lintfree cloth to avoid contamination and freeze-dried in a Zirbus 
TABLE 1 | Sedimentary cores, location detail, and corresponding landscape elements (Figure 2).

\begin{tabular}{|c|c|c|c|c|}
\hline Sample ID & Landscape unit & Coordinates & $\begin{array}{l}\text { Core depth below } \\
\text { surface (m.b.s.) }\end{array}$ & No of subsamples \\
\hline YUK15-YU-L7 & Alas lake in a drained lake basin & $61.76397^{\circ} \mathrm{N}, 130.46442^{\circ} \mathrm{E}$ & 20.00 & 5 \\
\hline YUK15-YU-L15 & Yedoma lake of first generation & $61.76086^{\circ} \mathrm{N}, 130.47466^{\circ} \mathrm{E}$ & 21.46 & 5 \\
\hline YUK15-YED-1 & Dry Yedoma hill & $61.75967^{\circ} \mathrm{N}, 130.47438^{\circ} \mathrm{E}$ & 22.35 & 7 \\
\hline YUK15-ALAS-1 & Dry Alas center in a refrozen drained lake basin & $61.76490^{\circ} \mathrm{N}, 130.46503^{\circ} \mathrm{E}$ & 19.80 & 5 \\
\hline BYK17-PG2410 & $\begin{array}{l}\text { Deposits under brackish water of the flooded } \\
\text { Uomullyakh-Kyuel Lagoon }\end{array}$ & $71.730,869^{\circ} \mathrm{N}, 129.274,831^{\circ} \mathrm{E}$ & 33.50 & 7 \\
\hline BYK17-PG2411 & $\begin{array}{l}\text { Deposits under brackish water of the flooded } \\
\text { Polar Fox Lagoon }\end{array}$ & $71.74303^{\circ} \mathrm{N}, 129.3383^{\circ} \mathrm{E}$ & 30.75 & 6 \\
\hline BYK17-PG2412 & $\begin{array}{l}\text { Sediments from Goltsovoye Lake } \\
\text { (thermokarst) and talik below }\end{array}$ & $71.74515^{\circ} \mathrm{N}, 129.30217^{\circ} \mathrm{E}$ & 36.65 & 6 \\
\hline
\end{tabular}

Sublimator 3-4-5. Afterwards, we split the samples for homogenization with a planetary mill (FRITSCH pulverisette 5) in agate jars and non-destructive analyses, like determining grain-size distribution. In total, we took 41 samples. Further details on the stratigraphic successions and sampling procedures can be found in Strauss et al. (2018), on Goltsovoye Lake (PG2412) in Jongejans et al. (2020), and in Jenrich et al. (2021) for the lagoon locations (PG2410 and PG2411).

\section{Biogeochemical Parameters \\ Soil Total Mercury}

We determined the soil total mercury (STHg) in solid material by thermal decomposition, amalgamation and atomic absorption spectrophotometry using a Direct Mercury Analyzer (DMA-80; MLS GmbH). The solid samples are combusted at about $750^{\circ} \mathrm{C}$ under a flow of oxygen, and the $\mathrm{Hg}$ in the off-gases is trapped as amalgam on a gold sieve. In a subsequent step, $\mathrm{Hg}$ is released and its amount is determined by atomic absorption spectroscopy. IAEA 456, a marine sediment, was used as reference material, six times within two consecutive days of measurement. The detection limit of the most sensitive cuvette was $<0.003 \mathrm{ng}$. For each sample, we measured STHg at least three times and up to six times if the results showed larger variations. Relative standard deviation of the replicates ranged from 0.4 to $11.7 \%$, with a median of $3.0 \%$ and a mean of $3.7 \%$.

$\mathrm{Hg}$ species $\left(\mathrm{Hg}^{0}, \mathrm{Hg}^{2+}, \mathrm{CH}_{3} \mathrm{Hg}^{+}\right)$were analyzed in three samples with higher $\mathrm{Hg}$ content using gas chromatography with atomic emission detection (GC-AED) as described in Frohne et al. (2012).

\section{Carbon and Nitrogen}

For the measurement of total carbon (TC) and total nitrogen (TN), we put $5.0-5.8 \mathrm{mg}$ of the homogenized sample material into zinc capsules, added tungsten oxide for better combustion and put them in the catalytic tube of an element analyzer (Elementar Vario EL III). We used empty capsules for background detection and included reference standards every 30 measurements to ensure correct results. The device has a specific accuracy and a detection minimum of $0.1 \mathrm{wt} \%$.

TOC was determined using pyrolysis, the thermo-chemical fission of organic compounds, with pure nitrogen (99.996\%) as carrier gas and an Elementar varioMAX C Analyzer. We measured different glutamic acids as reference material as well as empty containers at the beginning and always after 30 measurements for background determination. We measured TC, TN, and TOC twice per sample and calculated total inorganic carbon (TIC) content as the difference between TC and TOC.

\section{Sedimentological Methods Dry Bulk Density}

Bulk density $\rho_{\mathrm{b}}$ is the ratio of mass to volume of the dry sample and is a standard parameter for soil description. $\rho_{\mathrm{b}}$ of icesaturated sediment was determined following Strauss et al (2012) for all samples with a water content of more than $20 \mathrm{wt} \%$ (= "water saturated").

\section{Mass Specific Magnetic Susceptibility}

The mass specific magnetic susceptibility (MS) is a frequently used stratigraphic parameter and allows detecting variations of

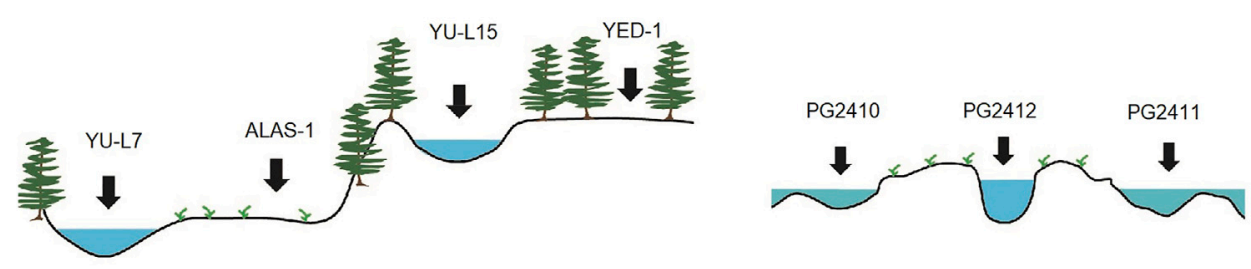

FIGURE 2| Schematic overview of coring locations (Table 1). Left: Yukechi Alas; bottom positions (YU-L7 and ALAS-1) below the dry Yedoma permafrost surface and top positions (YU-L15 and YED-1) with both terrestrial and thermokarst lake cores. Right: Bykovsky Peninsula; PG2410 and PG 2411 from lagoonal open water bodies, and PG2412 from a thermokarst lake. 


\section{STHg concentration per core}

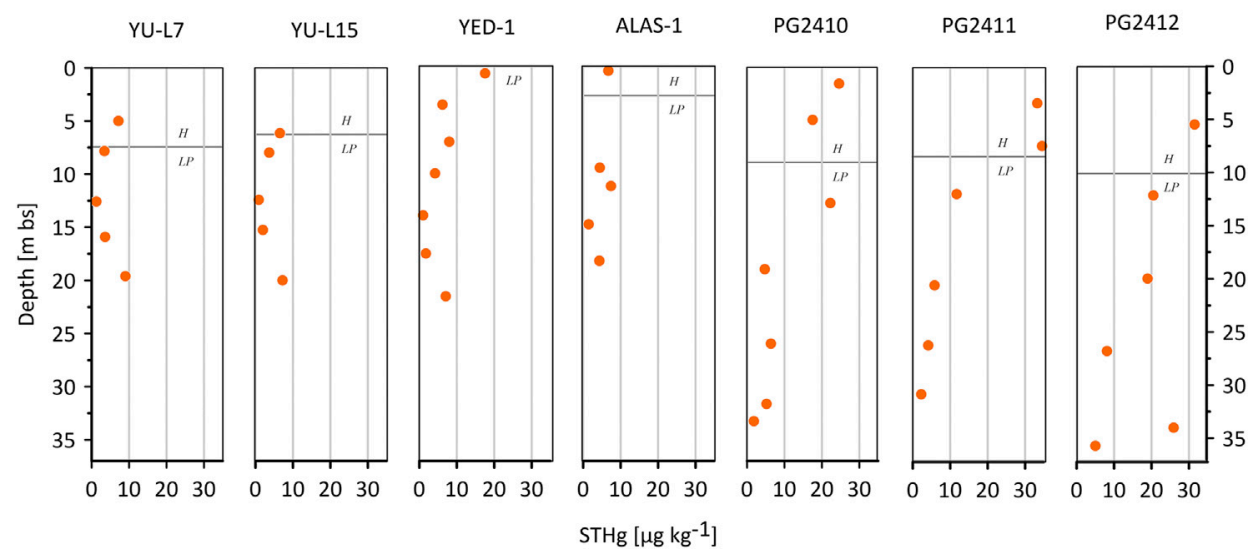

FIGURE 3 | Soil total Hg concentration plotted against depth for all seven cores investigated. H, Holocene; LP, late Pleistocene. Further information on lithology (grain size, frozen or unfrozen) can be found in Supplementary Figure A.

magnetic minerals within sediment layers. We measured MS with a Magnetic Susceptibility Meter (Bartington Instruments MS2, Sensor Type MS 2B) on the freeze-dried samples with a frequency of $0.465 \mathrm{kHz}$. MS is given as $\times 10^{-8} \mathrm{~m}^{3} \mathrm{~kg}^{-1}$.

\section{Grain Size}

The grain-size distribution is a central sedimentological parameter. In general, trace elements are expected to be enriched in finer sediments (e.g., Martin and Meybeck, 1979; Mwamburi, 2003). Prior to grain-size analyses, we removed all organic remains by using hydrogen peroxide. The samples were sieved for particles $>1 \mathrm{~mm}$ and for analyzing the finer fraction a laser particle sizer (Malvern Mastersizer 3000) was employed and tetrasodium pyrophosphate was used for grain dispersal. Size distributions and other statistical parameters were calculated after Folk and Ward (1957) using GRADISTATv8 (Blott and Pye, 2001) for particles $<1 \mathrm{~mm}$; when particles $>1 \mathrm{~mm}$ were included $\mathrm{R}$ studio was used.

\section{Statistical Analyses}

We carried out all statistical analyses using $\mathrm{R}$ studio (RStudio Team, 2020). To test a correlation between STHg and TOC, TIC, TN, clay content, silt content, sand content, and MS, we used the Spearman rank correlation coefficient $\left(r_{s}\right)$. This is a nonparametric procedure, not requiring a linear relationship between variables (Zar, 2005). The correlation is considered weak for $r_{s}<0.3$, moderate for $0.3<r_{s}<0.5$ and strong for $\mathrm{r}_{\mathrm{s}}=0.5$ or above. The decisive level of significance $(\alpha)$ was 0.01 .

Our second research question implies two null hypotheses: There are no significant differences in STHg accumulation between Holocene and late Pleistocene landscape elements $\left(\mathrm{H}_{0,1}\right)$ or between both study areas $\left(\mathrm{H}_{0,2}\right)$. To test these, a Mann-Whitney $U$ test for paired nonparametric data (Nachar, 2008) was performed. Here, a hypothesis is to be rejected when $\alpha$ exceeds 0.05 .

\section{RESULTS}

In addition to the specific descriptions below, we listed a full set of sedimentological and chemical results in the appendix and they are plotted for each core as multiplots (Supplementary Figure C). Throughout the following, the given variability measures are the standard deviation.

\section{Biogeochemistry \\ Soil Total Mercury}

The mean $\mathrm{Hg}$ concentration of all samples is $9.72 \pm 9.28 \mu \mathrm{g} \mathrm{kg}^{-1}$. The minimum value of $0.86 \pm 0.09 \mu \mathrm{g} \mathrm{kg}^{-1}$ was detected in YUL15 ( $12.42 \mathrm{~m}$ b.s.), the maximum concentration of $34.52 \pm$ $4.02 \mu \mathrm{g} \mathrm{kg}^{-1}$ in PG2411 (7.35 m b.s.). Concentrations clearly differ between the two study areas. Within each area there are no obvious patterns related to the landscape units studied.

At Yukechi, the arithmetic mean $\mathrm{Hg}$ concentration of all samples is $5.21 \pm 3.66 \mathrm{\mu g} \mathrm{kg}^{-1}$. Below $5 \mathrm{~m}$ the $\mathrm{STHg}$ concentration shows a similar trend in cores YU-L7, YU-L15, and YED-1 (Figure 3) with decreasing concentrations from 25 to $10 \mathrm{~m}$ depth and then increasing above. ALAS- 1 shows values in the same range, between 0 and $10 \mu \mathrm{g} \mathrm{kg}^{-1}$, but a slightly different pattern. We selected the cores to represent different landscape units and thus the similarity in $\mathrm{Hg}$ patterns shows no significant dependence on present day environment.

With a mean of $14.95 \pm 10.94 \mu \mathrm{g} \mathrm{kg}^{-1}$ the STHg concentration in sediments from the Bykovsky Peninsula is higher compared to Yukechi, with values up to $34.52 \mu \mathrm{g} \mathrm{kg}^{-1}$, and shows a wider range. Values generally increase towards the surface (up core; Figure 3). One sample from the lower part of PG2412 (33.85 mb.s.) shows a noticeably high STHg value. It originates from the vicinity of an organic rich deposit (wood remains; see Supplementary Figure A). Particularly in PG2411 an abrupt increase in STHg concentration above the transition of late Pleistocene sand to Holocene silt is apparent (see Figure 3 
TABLE 2 | Mean concentration of TC, TN, TOC, and TIC in the sediment samples from the Yukechi Alas (22 samples from 4 cores) and the Bykovsky Peninsula (19 samples from 3 cores).

\begin{tabular}{lcccc} 
& TC (wt\%) & TN (wt\%) & TOC (wt\%) & TIC (wt\%) \\
\hline Yukechi Alas & $1.33 \pm 0.69$ & $0.11 \pm 0.06$ & $0.63 \pm 0.57$ & $0.70 \pm 0.41$ \\
Bykovsky Peninsula & $2.58 \pm 2.25$ & $0.16 \pm 0.12$ & $2.13 \pm 2.22$ & $0.45 \pm 1.21$
\end{tabular}

and Supplementary Figure A); the increase is less in PG2010 and PG2412.

The values plotted in Figure 3 display the mean of all STHg measurements per sample. The standard deviation ranged from 0.04 to $4.02 \mu \mathrm{g} \mathrm{kg}^{-1}(0.4-18.9 \%)$ but this deviation plots within the symbol size for most samples and is therefore not shown.

The $\mathrm{Hg}$ speciation analysis $\left(\mathrm{Hg}^{0}, \mathrm{Hg}^{2+}, \mathrm{MeHg}^{+}\right)$in three samples with relatively high $\mathrm{Hg}$ concentrations (all from the Bykovsky Peninsula) revealed that, as expected, all detectable $\mathrm{Hg}$ is in the form of $\mathrm{Hg}^{2+}$. Still, the presence of methylated species in regularly thawing near-surface layers of terrestrial cores (YED-1, ALAS-1) cannot be excluded.

\section{Total Carbon, Total Nitrogen, and Total Organic Carbon}

TC, TN, and TOC concentrations are listed in Table 2 (see also Supplementary Table A and Supplementary Figure C). Distinct differences in TC, TN, and TOC are visible between both study regions whereas environmental setting or state of permafrost degradation within a region seem less important. The general down core trends at Yukechi show decreasing values in the upper half and increasing values below, whereas the TC, TN, and TOC values decrease with depth in the cores from Bykovsky Peninsula. TN and TOC values for samples below detection limit $(<0.1 \mathrm{wt} \%)$ were assumed to be $0.05 \mathrm{wt} \%$. The trend of TIC with depth is less consistent within the study areas.

\section{Sedimentology}

\section{Lithology, Water Content, and Bulk Density}

Detailed descriptions of sediment characteristics for Yukechi can be found in Jongejans et al. (2020); Windirsch et al. (2020); Ulrich et al. (2021). In brief, the sediment cores analyzed revealed different types of permafrost including Yedoma deposits (silty sediment from the late Pleistocene), thermokarst sediments, fluvial sediments (sandy sediments from the late Pleistocene and Holocene), lake/lagoon sediments, and alas deposits.

Sediments recovered by coring from the Yukechi Alas showed the following characteristics: Core YU-L15 reveals silty to siltysand Ice-Complex deposits of late Pleistocene age (Ulrich et al., 2021). Sediments of the YU-L7 core were unfrozen when recovered and contain predominantly silt with clay and sand beds in places. Core YED-1 contains silty and sandy layers and was largely frozen when recovered. Part of an ice wedge is present between 7 and $10 \mathrm{~m}$ b.s. while the lowest meter of the YED-1 core is characterized by dense horizontal micro ice lenses. The ALAS-1 core is characterized by unfrozen silt to silty sand in the upper half and frozen silt below. The ALAS-1 core revealed a frozen organic layer more than half a meter thick at the top. Ice lenses up to $3 \mathrm{~mm}$ thick were found throughout the core.

Core PG2410 revealed three frozen layers. The upper $8 \mathrm{~m}$ consist of dark grey to black silt, with layers of coarse sand intercalated. The rest of the core contains greenish grey to medium grey sand with individual pebbles in the depth interval 9-14 $\mathrm{m}$ b.s. The second core from a lagoon, PG2411, contained prominent gravel up to $4 \mathrm{~cm}$ in diameter in a coarsegrained section between about 22 and $28 \mathrm{~m}$ b.s. Smaller pebbles can be found throughout. Detailed descriptions of the sediment characteristics of these two lagoon cores can be found in Jenrich et al. (2021). The mostly unfrozen sediment core PG2412 shows alternating fine, medium, and coarse sand layers, with pebbles in places. An organic layer with macroscopic wood remains was recovered between 34 and $35 \mathrm{~m}$ b.s. The range of water contents and mean dry bulk density (for water saturated samples only) are listed in Table 3.

\section{Mass-Specific Magnetic Susceptibility}

MS values show similar trends in all cores from the Yukechi Alas with variable values throughout each core, but the general trend increases from the top to the middle of the cores and decreases from the middle to the bottom. The highest MS of all Yukechi cores was measured in the ALAS-1 core at a depth of $14.75 \mathrm{~m}$ b.s. with a value of $257 \times 10^{-8} \mathrm{~m}^{3} \mathrm{~kg}^{-1}$, the minimum was $56 \times$ $10^{-8} \mathrm{~m}^{3} \mathrm{~kg}^{-1}$ in YU-L7 (5.00 $\mathrm{m}$ b.s.).

At Bykovsky Peninsula most of the sediments of PG2410, PG2411, and PG2412 show a MS lower than $50 \times 10^{-8} \mathrm{~m}^{3} \mathrm{~kg}^{-1}$. Maximum values occur in a depth range between 26.60 and $33.30 \mathrm{~m}$ b.s. The highest MS of $234 \times 10^{-8} \mathrm{~m}^{3} \mathrm{~kg}^{-1}$ was measured in PG2410 at $33.25 \mathrm{~m}$ b.s.; the lowest MS was $20 \times 10^{-8} \mathrm{~m}^{3} \mathrm{~kg}^{-1}$ in PG2412 (33.85 m b.s.).

\section{Grain-Size Distributions}

The fine fractions $(<1 \mathrm{~mm})$ of all samples show poor to very poor sorting and a dominance of silty to sandy grain sizes (see Supplementary Figure D; weight proportions of clay, silt, and sand, and fractions $>1 \mathrm{~mm}$ are listed in Supplementary Table B). In sediment successions from Yukechi, sandy silt is predominant with mostly unimodal and poorly sorted size distributions. Sediment sequences from Bykovsky on average show coarser grain sizes, dominated by sand, more diverse (bi- to polymodal) size distributions, and very poor sorting. The Bykovsky cores also reveal fine layers with clay contents up to $18.5 \%$, whereas the highest clay content in Yukechi sediments is only 9.2\%. Particles $>1 \mathrm{~mm}$ in diameter were found in all cores from Bykovsky, predominantly in PG2410 and PG2411 with >10 wt\%; just one sample from Yukechi core YU-L7 contained larger clasts.

\section{Statistical Mann-Whitney $U$ test}

The second research question implied two null hypotheses: There are no significant differences in STHg accumulation between Holocene and late Pleistocene landscape elements $\left(\mathrm{H}_{0,1}\right)$ or between both study areas $\left(\mathrm{H}_{0,2}\right)$. Based on the Mann-Whitney $U$ test we reject both null hypotheses. The test for $\mathrm{H}_{0,1}$ revealed $\mathrm{W}=$ 223 and $\alpha=0.01$. The test for $\mathrm{H}_{0,2}$ resulted in $\mathrm{W}=319$ and $\alpha<0.1$. 
TABLE 3 |Water content and dry bulk density for all water-saturated samples of the seven studied sediment cores. Note that water content represents ground-ice content in the frozen parts of all cores except $Y U-L 7$, which was completely unfrozen during drilling.

\begin{tabular}{|c|c|c|c|c|}
\hline & & \multicolumn{2}{|c|}{ Water content [wt\%] } & \multirow{2}{*}{$\frac{\rho b\left[\mathrm{~g} / \mathrm{cm}^{3}\right]}{\text { Mean }}$} \\
\hline & & Min & Max & \\
\hline \multirow[t]{4}{*}{ Yukechi Alas } & YU-L15 & 15.70 & 38.56 & $1.27 \pm 0.16$ \\
\hline & YU-L7 & 12.47 & 22.60 & 1.43 \\
\hline & YED-1 & 21.34 & 57.48 & $1.11 \pm 0.29$ \\
\hline & ALAS-1 & 15.46 & 23.51 & $1.43 \pm 0.03$ \\
\hline \multirow[t]{3}{*}{ Bykovsky } & PG2410 & 9.83 & 25.64 & $1.36 \pm 0.04$ \\
\hline & PG2411 & 9.16 & 47.74 & $0.95 \pm 0.26$ \\
\hline & PG2412 & 14.88 & 54.35 & $1.08 \pm 0.42$ \\
\hline
\end{tabular}

\section{DISCUSSION}

We sought to answer two concrete research questions: 1) Is there a difference in $\mathrm{Hg}$ concentration in deep permafrost soils of Yedoma landscapes compared to shallow levels? 2) To what extent can distinct permafrost landscape features (late Pleistocene permafrost vs. Holocene permafrost, lake or lagoon deposits vs. dry Alas or Yedoma deposits) be clearly distinguished in terms of their $\mathrm{Hg}$ enrichment?

First, we discuss both questions and then further aspects, particularly the relation of $\mathrm{Hg}$ to $\mathrm{TOC}, \mathrm{TN}$ and sedimentation regime. Conclusive, we give an outlook to potentially initiated $\mathrm{Hg}$ dynamics in the Arctic with ongoing permafrost thaw.

\section{Mercury Content Compared to Other Arctic Studies}

We found detectable $\mathrm{Hg}$ concentrations in the deep permafrost deposits from Siberian Yedoma-characterized landscapes. The number of samples were limited in this study, however, we can expect them to be unaffected by anthropogenic Hg input. Most of our samples are of pre-industrial age, as derived from radiocarbon age determination by Jongejans et al. (2020), Windirsch et al. (2020) and Ulrich et al. (2021) (see also Supplementary Figure C). In our study, the STHg concentration ranges from 0.86 to $34.52 \mu \mathrm{g} \mathrm{kg}^{-1}$ with a mean of $9.72 \pm 9.28 \mu \mathrm{g} \mathrm{kg}^{-1}$. The median is $6.38 \mu \mathrm{g} \mathrm{kg}^{-1}$. This amount is lower compared to that found in the investigation of Alaskan near-surface permafrost layers (upper $3 \mathrm{~m}$ ) described by Schuster et al. (2018); those samples contained an average of $43 \pm$ $30 \mu \mathrm{g} \mathrm{kg}^{-1}$ STHg, but were within the same order of magnitude as our samples. We have only a few subsamples from a similar depth because we looked more at deep deposits, so a direct comparison would be insufficient, but the sediment layers that are closest to the surface revealed also higher mean STHg concentrations in our study $\left(17.64 \pm 10.40 \mu \mathrm{g} \mathrm{kg}^{-1}\right.$ in all subsamples from the uppermost $3.5 \mathrm{~m}$ ). For comparison, $55 \pm$ $11 \mu \mathrm{g} \mathrm{kg}^{-1}$ were found in near-surface peat cores from permafrost mires in the Stordalen area (Northern Sweden) and $66 \pm$ $24 \mathrm{~g} \mathrm{~kg}^{-1}$ in lake sediments from the same region (preindustrial layers in both cases) (Rydberg et al., 2010). Munthe et al. (2007) found 2-5 fold higher $\mathrm{Hg}$ concentrations in recent lake sediment layers compared to historical ones in Scandinavia. However, our Yukechi cores also show similar STHg

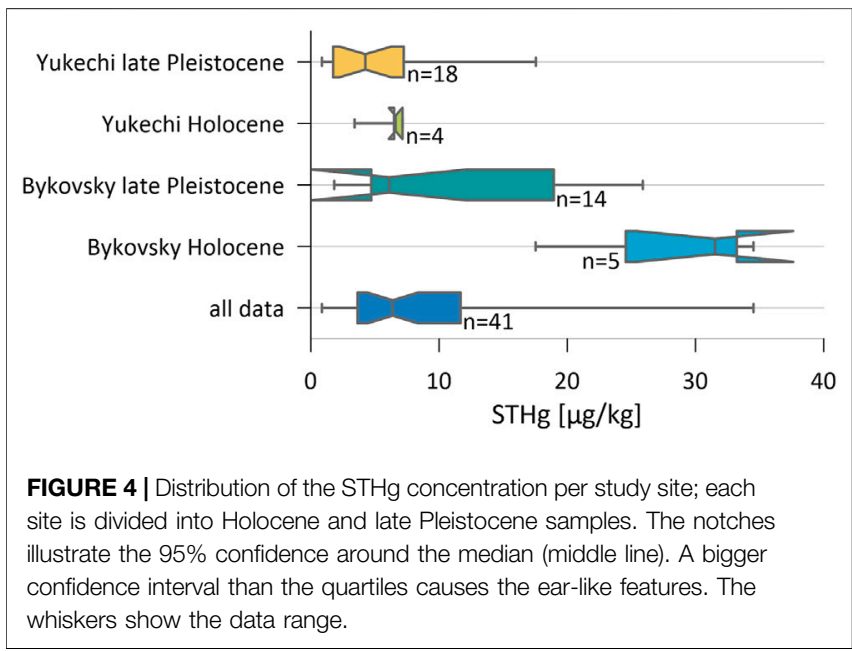

concentrations in the deepest layers compared to the nearsurface samples, as Figure 3 shows. The uppermost section from the YED-1 land surface core contains the highest STHg of this core, while in ALAS-1 (also drilled from the land surface) this section is unremarkable. Based on our findings, we suggest that young layers on the land surface, relatively recently affected by atmospheric deposition, do not necessarily contain strikingly higher STHg concentrations.

\section{Differences Between the Study Areas}

In consequence of our rejected null-hypotheses, we report that there are differences in STHg concentration with respect to both geochronology and study location. However, the difference between the study areas is more pronounced than between the stratigraphical units as shown by the boxplots in Figure 4. The Holocene material from Yukechi is similar to the late Pleistocene material from Bykovsky in STHg, but much lower than Bykovsky's Holocene layers. We cannot see clear differences in $\mathrm{Hg}$ concentrations between the different landscape elements within one study area. For example, the cores from the Yukechi Alas showed similar trends of $\mathrm{Hg}$ with depth, independent from whether they derived from a thermokarst lake, a dry alas basin, dry Yedoma surface or a first-generation lake in Yedoma remains (see Figure 3; Supplementary Figure C). 
As noticed by e.g., Douglas et al. (2005), Hg enrichment in Artic areas close to the sea is elevated. Recent studies by St. Pierre at al. (2015) or Douglas and Blum (2019) show evidence for this in Arctic soils and snowpacks, respectively. They explain their findings, inter alia, with the springtime atmospheric $\mathrm{Hg}$ depletion events (AMDEs). Every year during springtime, the amount of gaseous elemental $\mathrm{Hg}$ (GEM) in the air is lower than usual, particularly along polar coasts. Involving oxidizing reactions with halogens, the GEM is rapidly deposited to the environment and therefore vanishes from the atmosphere (Steffen et al., 2008). As those photochemical processes with halogen are strongly linked to the Arctic open water areas, the soil is also characterized by higher $\mathrm{Hg}$ enrichment compared to Arctic inland areas (St. Pierre et al., 2015). Analogous to this, the Arctic coastal spring snowpack is also enriched in $\mathrm{Hg}$ until snowmelt. The majority of the GEM is re-emitted to the atmosphere earlier, but about 9-24\% are further transported with spring runoff and, inter alia, deposited to the ground or uptaken by vegetation (Douglas and Blum, 2019). St. Pierre et al. (2015) also reported, that lichens in the Canadian Arctic were highly enriched in $\mathrm{Hg}$ compared to underlying soils. As other non-vascular plants (e.g., moss), lichens take up more $\mathrm{Hg}$ than vascular plants (Olson et al., 2019). Although the surface of Bykovsky Peninsula is not highly covered with lichens, they are more present there than in the Yukechi Alas region. Also, the moss layer on the North Yakutian peninsula is denser developed than in Central Yakutia, where the landscape is more anthropogenically influenced. $\mathrm{Hg}$ uptaken by non-vascular vegetation gets incorporated into the soil with ongoing sedimentation over thousands of years. This, together with the mentioned correlation of $\mathrm{Hg}$ and the proximity to Arctic open waters supports our findings of higher $\mathrm{Hg}$ concentrations in the North Yakutian sediment, close to the Laptev Sea. Interestingly the alas sediment core (ALAS-1) does not show distinctly lower $\mathrm{Hg}$ concentrations overall, although nonvascular plants play little to no role in the current vegetational cover. However, the uppermost and youngest investigated layer of the deposits is only half as concentrated in $\mathrm{Hg}$ than compared to the uppermost layer of the Yedoma core (YED-1) which derives from a more moss-dominated surrounding. In addition, according to Ulrich et al. (2017) and Katamura et al. (2009), the development of alas depressions as well as the current forest and grassland vegetation is younger than the rest of the investigated layers in both cores. Therefore, the vegetational influence to $\mathrm{Hg}$ enrichment might have changed over the last 6,500 years in the Yukechi Alas. Furthermore, natural wild fires occurred throughout the Holocene until today (Katamura et al., 2009; Glückler et al., 2021), which also leads to depletion of mercury in soil surface and vegetation.

\section{Total Mercury/Total Organic Carbon Ratio}

In modern literature, the ratio of STHg/TOC $\left(\mathrm{R}_{\mathrm{HgC}}\right)$ is used for a first rough estimation of the Arctic $\mathrm{Hg}$ reservoir. TOC data are available for several areas in the Arctic zone (e.g., Schuster et al., 2018; Lim et al., 2020) and it has been shown that Hg strongly correlates with OM (Sanei et al., 2012; Lim et al., 2019). Our data also show a strong positive correlation between STHg and TOC $\left(\mathrm{r}_{\mathrm{s}}=0.78, p<0.01\right)$.

Schuster et al. (2018) found a median $\mathrm{R}_{\mathrm{HgC}}$ of $1.6 \mu \mathrm{g} \mathrm{Hg} \mathrm{g} \mathrm{C}^{-1}$ in Alaskan Arctic shallow permafrost soils to a depth of three $\mathrm{m}$. Therefore, they estimated the permafrost region of the Northern Hemisphere to contain twice as much $\mathrm{Hg}$ as all other soils, the atmosphere, and the ocean combined. Lim et al. (2020) suggest a lower value for the Northern Hemisphere $\mathrm{Hg}$ pool, based on studies in the Western Siberian lowlands. They calculated a lower median $\mathrm{R}_{\mathrm{HgC}}$ of $0.19 \mathrm{Gg} \mathrm{Hg} \mathrm{PgC}^{-1}$ for organic soils and $0.63 \mathrm{Gg} \mathrm{Hg} \mathrm{Pg} \mathrm{C}{ }^{-1}$ for mineral soils.

We calculate a total $\mathrm{R}_{\mathrm{HgC}}$ mean for all samples of $2.57 \mu \mathrm{g} \mathrm{Hg} \mathrm{g} \mathrm{C}^{-1}$. This observation could lead to the assumption of a larger Arctic STHg pool (at least when including deeper permafrost deposits) than suggested by Schuster et al. (2018). Excluding all samples with TOC below detection limit (we assumed a value of $0.05 \mathrm{wt} \%$ ), the mean $\mathrm{R}_{\mathrm{HgC}}$ becomes considerably lower, namely $0.77 \mu \mathrm{g} \mathrm{Hg} \mathrm{g} \mathrm{C}^{-1}$. Charbonnier et al. (2020) point out that this ratio must be interpreted carefully because post-depositional degradation of OM does not necessarily affect the $\mathrm{Hg}$ concentration, which could lead, in turn, to a misleadingly high STHg/TOC ratio. Giesler et al. (2017) also state that a higher $\mathrm{R}_{\mathrm{HgC}}$ value can indicate an increase in post-depositional OM decomposition, but that the latter is, in turn, also linked to the enrichment of $\mathrm{Hg}$ in soil as a by-product.

Because our two study sites show clear differences in STHg/ TOC as well, we are skeptical about this method for a pan-Arctic $\mathrm{Hg}$ reservoir estimation. Across the cores from the Bykovsky Peninsula, the mean $\mathrm{R}_{\mathrm{HgC}}$ is $2.02 \mu \mathrm{g} \mathrm{Hg} \mathrm{g} \mathrm{C}^{-1}$ with a clearly visible correlation between $\mathrm{Hg}$ and TOC (Figure 5A); it is higher for the Yukechi study site $\left(3.05 \mu \mathrm{g} \mathrm{Hg} \mathrm{g} \mathrm{C}{ }^{-1}\right)$, but with no correlation (Figure 5B). In general, we assume that $\mathrm{OM}$ decomposition, weathering, and biological activity are significantly reduced in the frozen Yukechi sediments, but the higher $\mathrm{R}_{\mathrm{HgC}}$ might also be caused by the higher number of samples from this study site with TOC below detection limit.

Our number of samples and study sites is limited compared to the whole Arctic region. Nonetheless, if we combine our mean $\mathrm{R}_{\mathrm{HgC}}$ of $2.57 \mu \mathrm{g} \mathrm{Hg} \mathrm{g} \mathrm{C}{ }^{-1}$ with the estimation of the OC pool in the Siberian Yedoma regions $(211 \mathrm{Gt}$ OC stored in the frozen deposits; Strauss et al. (2013)), we could estimate a total STHg pool of approximately 542 gigagram $\left(1 \mathrm{Gg}=10^{6} \mathrm{~kg}=1,000 \mathrm{t}\right)$ in those areas. Lim et al. (2020) suggest a similar pan-Arctic permafrost $\mathrm{Hg}$ pool of $597 \mathrm{Gg}(384-750 \mathrm{Gg})$ in the upper $3 \mathrm{~m}$. Further studies could refine those findings.

Our statistical test revealed a non-significant weak negative correlation between STHg and TIC $\left(r_{s}=-0.18, p=0.24\right)$. Therefore, we disregard TIC in our further discussion.

\section{Sedimentation Regime as Potential Controlling Factor}

Grain-size distribution reveals information about transport and sedimentation regimes and might allow conclusions about depositional conditions. Strauss et al. (2012) established an interpretation of grain-size distribution diagrams from 

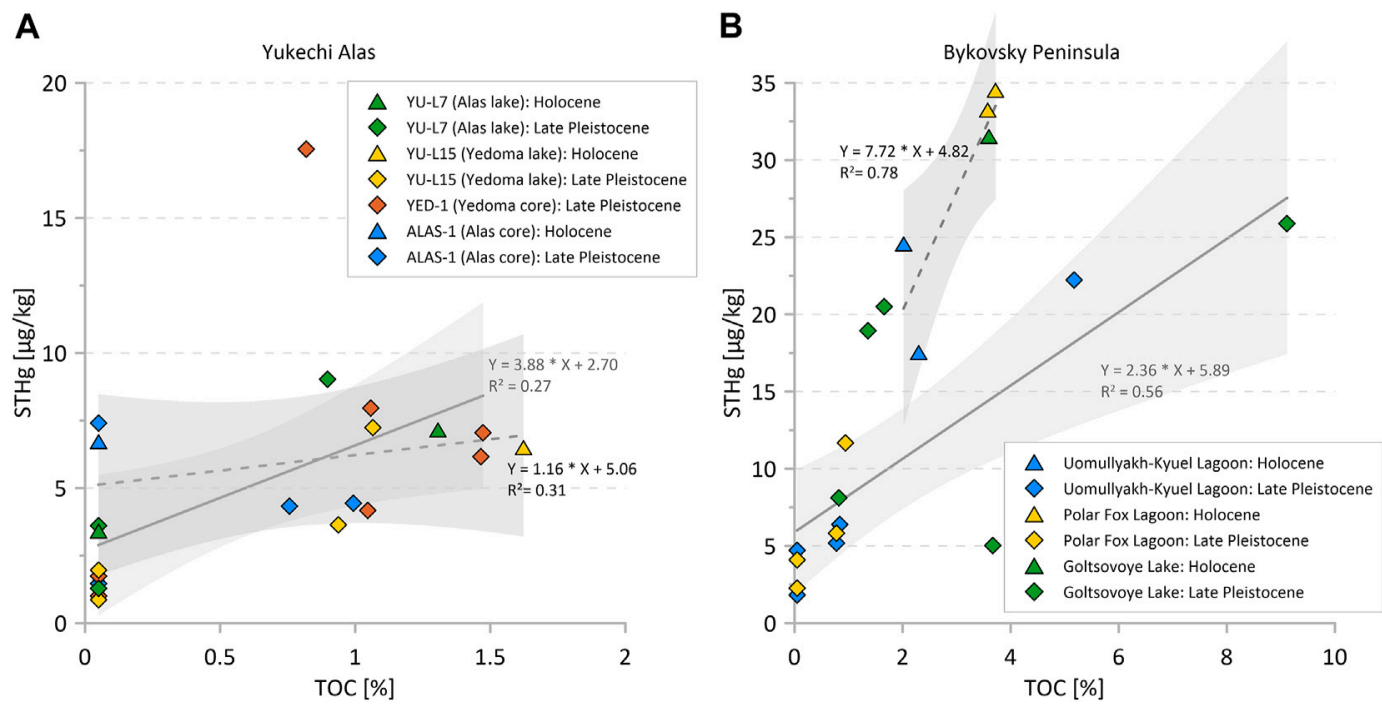

FIGURE 5 | Plot of STHg vs. TOC, (A) for all samples from the Yukechi Alas with a $\mathrm{R}_{\mathrm{HgC}}$ of $3.05 \mu \mathrm{gg} \mathrm{Hg}^{-1}$ but no clear correlation; (B) for all samples from the Bykovsky Peninsula. The correlation is positive with a $\mathrm{R}_{\mathrm{HgC}}$ of $2.02 \mu \mathrm{g} \mathrm{Hg} \mathrm{g} \mathrm{C}{ }^{-1}$. The equations of the linear regressions and the $R^{2}$ are given in color: Holocene is the black dashed line, late Pleistocene is grey.

Yedoma environments in terms of sedimentation regimes. Every peak in the curves is caused by a different deposition process. A sand maximum, for example, indicates a higher energy level during transport, because a certain energy level is needed to transport coarse particles. We found a distinct maximum in the sandy regime in all samples from the Bykovsky Peninsula and the Yukechi study site. The bi- to multi-modal grain-size distributions (see Supplementary Figure D) suggest that more than one process influenced sediment transport and deposition, which is typical for Siberia's deep ice-bearing permafrost deposits that developed under a very cold and highly continental climate (e.g., Schirrmeister et al., 2011; Strauss et al., 2017). Based on grain-size distribution, the aeolian and alluvial/fluvial transport and depositional processes seem to dominate in these study areas, which is consistent with the findings of Strauss et al. (2012). Schirrmeister et al. (2020) support the hypothesis of polygenetic sedimentation regimes in those types of landscapes, involving alluvial, fluvial, and aeolian transport, in situ frost weathering, as well as post-depositional processes.

Water and air fluxes are also suggested to be the main transport media of $\mathrm{Hg}^{2+}$ from uplands (watershed area) to reducing zones (wetlands, coastal areas, etc.). Even if the transport by riverine fluxes might be small on a global scale, it can be a substantial pathway in coastal areas (Driscoll et al., 2013; Zolkos et al., 2020).

Although the material of the Bykovsky cores is sandier on average, it is also more poorly sorted and contains more clay. This has an impact on the STHg, as well. As Figure 6A shows, there is a positive correlation between STHg and clay content $\left(\mathrm{r}_{\mathrm{s}}=0.58, p<\right.$ 0.01 ). This is in accordance with most statements in literature about elemental deposition in sediments and can be explained by the increased specific surface area and the structural properties of clays (Whitney, 1975; Zonta et al., 1994) as well as ionic charge (clay's net charge is often negative (Barton and Karathanasis, 2002) which allows binding to positive $\mathrm{Hg}$ ions, as for example $\mathrm{Hg}^{2+}$ ). On the contrary, the Spearman test revealed a weak but not significant correlation for STHg vs. silt content $(0.3, p$-value $>$ 0.01 ) and a moderate negative correlation for STHg and sand content $(-0.47, p$-value $<0.1)$. Figure $6 \mathbf{B}$ shows that the correlation of mean grain size and STHg is negative exponential. In consequence, STHg increases with finer mean grain size, or higher clay content. This leads us to the statement that in the finer-grained and more organic-rich Holocene sediments, $\mathrm{Hg}$ is significantly enriched. The siltier sediment in Yedoma landscapes tends to contain less $\mathrm{Hg}$. Still, we found comparable levels of $\mathrm{Hg}$ in late Pleistocene sediments, too, but always accompanied by elevated TOC levels.

Our results showed that an enhanced MS $\left(100 \times 10^{-8} \mathrm{~m}^{3} \mathrm{~kg}^{-1}\right.$ and above) is accompanied by relatively low STHg and vice versa (see Figure 6C). Spearman's rank correlation coefficient with subsequent significance testing revealed a strong negative correlation of $-0.71(p<0.01)$. The correlation between MS and heavy metal concentration (not only in Arctic regions) has already been discussed, by e.g., Hanesch and Scholger (2002); Schmidt et al. (2005); Wang and Qin (2005). These results indicate that the correlation of heavy metals with MS is variable, presumably dependent upon the minerals present. Because there are mostly anaerobic and thus reducing conditions in these predominantly deep permafrost deposits and additionally low signals for MS, less oxidized minerals might dominate here. In contrast, more oxidized minerals are expected to be found in samples with higher MS and thus under less reducing conditions (Mullins, 1977). This observation might suggest that less oxidized minerals (in a reducing Arctic environment) are associated with enhanced $\mathrm{STHg}$ concentration. Even though the reduction of $\mathrm{Hg}^{2+}$ results in 
A

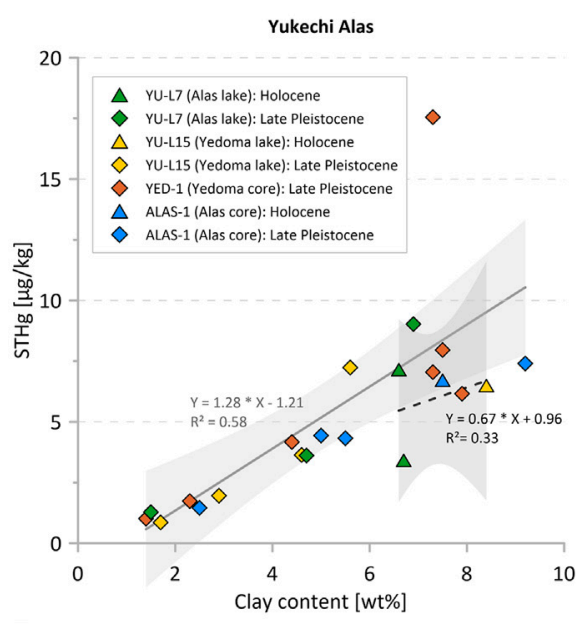

B

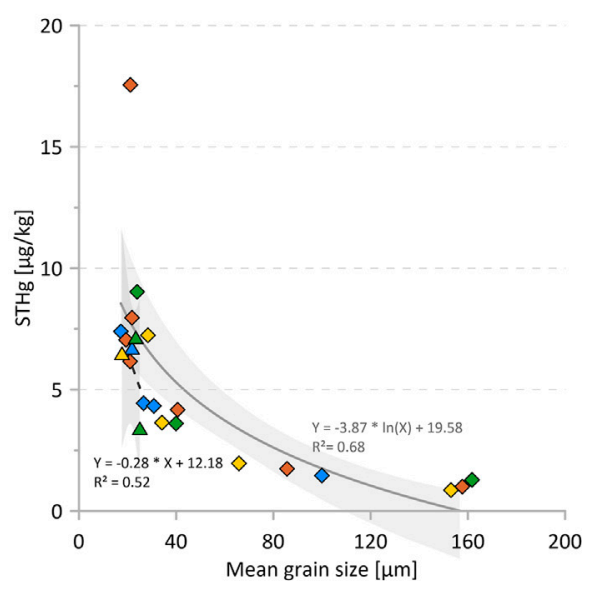

C

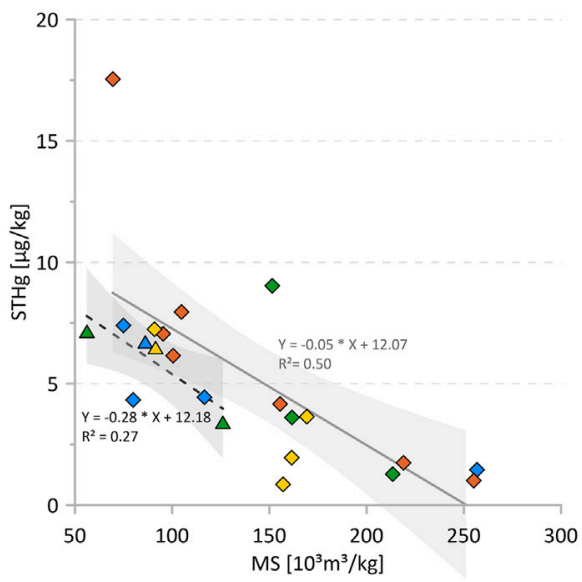

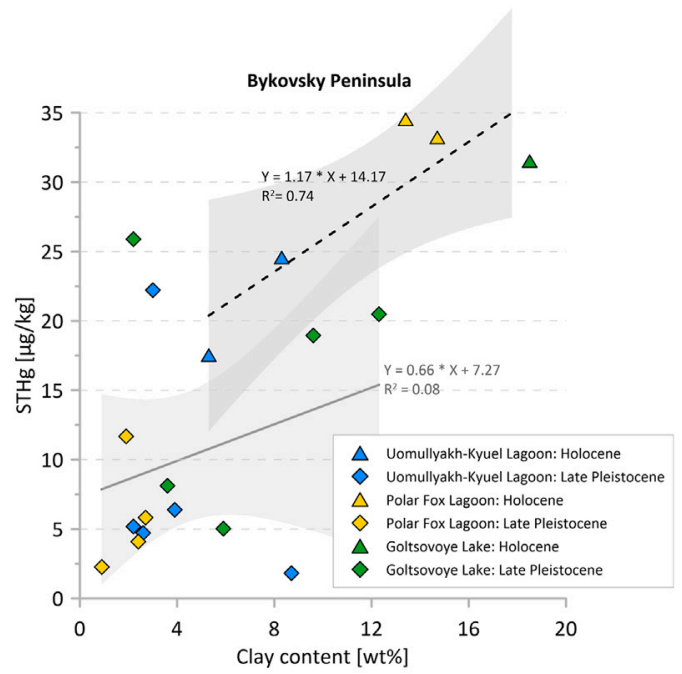
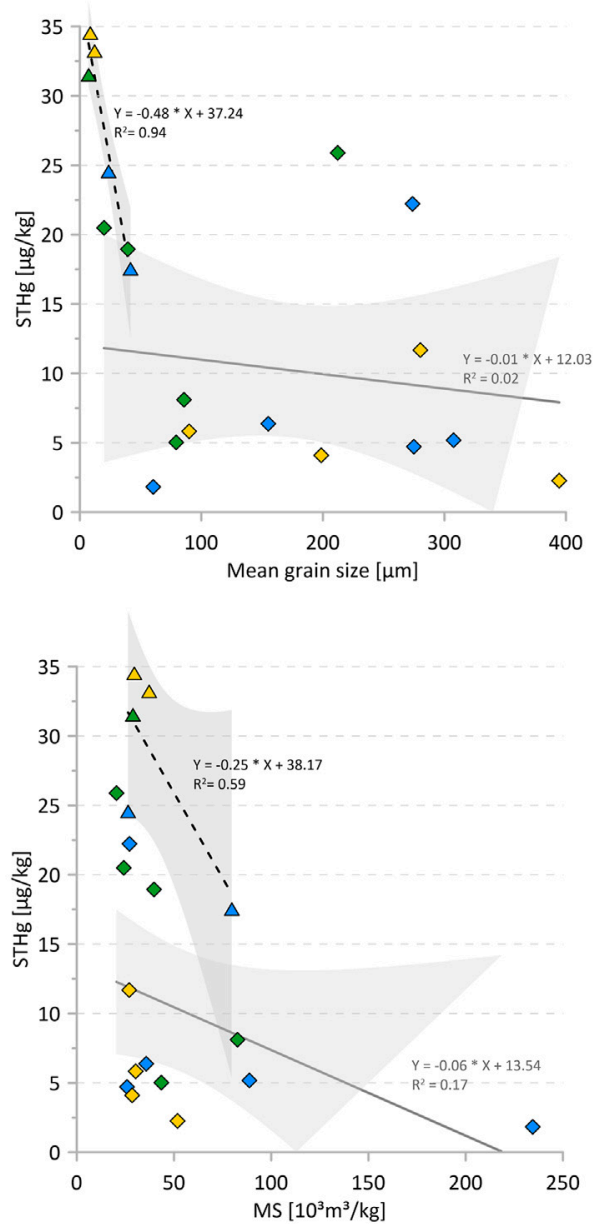

FIGURE 6 | Correlation of STHg with (A) clay: A positive correlation occurs between clay content and STHg concentration; (B) mean grain size: The correlation between the mean grain size and STHg is clearer in the Yukechi Alas than on Bykovsky Peninsula, caused by sorting quality. Grain-size distribution is better sorted in the Yukechi Alas; (C) MS: The correlation here is negative in general but, again, clearer in the Yukechi Alas. The equations of the linear regressions and the $R^{2}$ are given in color: Holocene is the black dashed line, late Pleistocene is grey. The legend given in (A) is the same in (B) and (C). 
volatile elemental $\mathrm{Hg}^{0}$, a loss of STHg via volatilization is only probable for topsoil layers interacting with the atmosphere. Nonetheless, because an enrichment of $\mathrm{Hg}$ or less degradation under anaerobic conditions is unlikely, we cannot give a reliable reason for the observed negative correlation of MS and STHg in this study without further investigations.

\section{Correlation of Total Mercury and Total Nitrogen}

TN was relatively low in general but comparable to what was observed in other Arctic studies (e.g., Lenz et al., 2013; Schirrmeister et al., 2013). Moreover, the TN concentration in sediment has been found to be positively correlated with carbon concentration (Faure, 1986), which we could also confirm in this study. Spearman's rank correlation for TN vs. TC is 0.75 , while for TN vs. TOC it is $0.87(p<0.01)$.

We found a strong linear positive correlation between TN and STHg $\left(\mathrm{r}_{\mathrm{s}}=0.72, p<0.01\right)$, but we cannot distinguish if there is a direct biochemical connection or if that observation can only be explained by the positive correlation of both TN and STHg with TC/TOC and clay content. A strong positive correlation of $\mathrm{Hg}$ and $\mathrm{N}$ in mineral soils and litter was reported from non-Arctic studies, e.g., in the Sierra Nevada by Obrist et al. (2009), but the authors also highlight that comparing the factors determining $\mathrm{Hg}$ contents across different sites is challenging. An analysis of nitrogen speciation would enable a deeper analysis and interpretation of TN and its composition.

\section{Biogeochemical Dynamics of Mercury Potentially Initiated by Thawing Arctic Permafrost}

We confirmed the positive correlation between $\mathrm{Hg}$ concentration and clay content for Arctic permafrost environments in this study, but above all, between $\mathrm{Hg}$ and TOC. Clay particles often have a net negative chemical charge (Barton and Karathanasis, 2002). For instance, in case of erosion, $\mathrm{Hg}$ is transported as particle-bound $\mathrm{Hg}^{2+}$. The interaction with TOC is more complex and has been discussed in the scientific literature already: Positive ions such as $\mathrm{Hg}^{2+}$ also bind to negatively charged OM components. Most $\mathrm{Hg}$ bound to soil organic matter (SOM) occurs with reduced sulfur groups (Giesler et al., 2017). Furthermore, SOM is considered to be a natural chelation agent for the biochemical process of organic acids binding metal ions (Sohalscha et al., 1967; Nowack and VanBriesen, 2005), which might also explain the coupling of soil carbon and $\mathrm{Hg}^{2+}$, but uncertainties still exist (Giesler et al., 2017). Nevertheless, the mineralization of SOM leads to the reduction of $\mathrm{Hg}^{2+}$ to $\mathrm{Hg}^{0}$ as a byproduct of soil respiration (Driscoll et al., 2013). Direct photolysis also leads to the reduction of $\mathrm{Hg}^{2+}$ to $\mathrm{Hg}^{0}$ (Ravichandran, 2004). Because $\mathrm{Hg}^{0}$ is volatile this causes reemission to the atmosphere, at least from surface soil layers. The retention time of $\mathrm{Hg}$ in the atmosphere is about 0.5 to 1 year, so from there it can be redeposited globally or at least within the hemisphere (Driscoll et al., 2013).
At the same time, current permafrost thaw and active layer deepening results in increasing mineralization of freeze-locked $\mathrm{OM}$, increasing microbial activity and vulnerability to erosional processes. As a consequence of this biogeochemical correlations, rapid, deep thaw of deposits in Yedoma environments releases significant amounts of OC and nitrogen (e.g., Kanevskiy et al., 2016; Fuchs et al., 2020). Hence, the release of significant $\mathrm{Hg}$ amounts into aquatic ecosystems via sediment transport is also likely. Under reducing conditions as for example in wetlands, coastal zones, and (nearly) water saturated permafrost deposits after thawing, bacterially mediated methylation processes occur, mostly driven by sulfate-reducing bacteria (Ullrich et al., 2001; Skyllberg et al., 2006). Methylation is a key step of the global Hg cycle in aquatic systems, particularly of inorganic $\mathrm{Hg}$ (mostly $\mathrm{Hg}^{0}$ or $\mathrm{Hg}^{2+}$ ) to $\mathrm{MeHg}^{+}$(Ullrich et al., 2001). So even if the input of already methylated species like $\mathrm{CH}_{3} \mathrm{Hg}^{+}$into the ocean via fluvial or erosional fluxes is relatively small (Driscoll et al., 2013), the potential of producing toxic $\mathrm{Hg}$ species in surface water and shallow ocean layers increases with the input of inorganic $\mathrm{Hg}$ as found in our samples. This is proven by e.g., Lehnherr et al. (2011) and Soerensen et al. (2016). In contrast to Driscoll et al. (2013); St. Pierre et al. (2018) confirmed already elevated aquatic $\mathrm{MeHg}$ concentration downstream of Arctic retrogressive thaw slump debris tongues and MacMillan et al. (2015) found significantly higher MeHg levels in Canadian thaw ponds on top of degrading ice wedges. In addition, due to climate change, the season for $\mathrm{Hg}$ methylation is extending, as annual thawing begins earlier and freezing starts later (Stern et al., 2012). MeHg is toxic for humans and animals, as it enters the central nervous system via the digestive tract (Ha et al., 2017) and accumulates along the food chain (Carneado et al., 2015). Human exposure is mainly through consumption of fish and other seafood, an important part of the traditional diet of Arctic communities (Duhaime et al., 2004). Thus, $\mathrm{MeHg}$ input to the polar ecosystem with ongoing permafrost thaw poses a significant hazard to local populations. In 2017, about 4.9 million people were living on permafrost soils with about $20 \%$ of these living on the coast (Ramage et al., 2021).

Dissolved organic matter (DOM) also plays an important role in transporting metal pollutants, because humic matter has redox properties that bind cations like $\mathrm{Hg}^{2+}$ to anionic OM (Tipping, 2002). Munthe et al. (2007) reported increased Hg levels in fish from lakes with higher DOM. It is likely that parts of OC in the investigated aquatic environments are present as DOM with a strong ionic binding to metal ions (Ravichandran, 2004).

Terrestrial inputs by sediment of degrading permafrost enriched with $\mathrm{OM}$, are one of the major sources of particulate Hg into Arctic streams (Schuster et al., 2011; Sonke et al., 2018; St. Pierre et al., 2018; Lim et al., 2019; Zolkos et al., 2020), which contribute more than $10 \%$ of the global river discharge into the Arctic oceans (Zolkos et al., 2020). Mu et al. (2019) and Zolkos et al. (2020) investigated the average export of $\mathrm{Hg}$ by the major Arctic rivers from 2012-2015 and 2012-2017, respectively. Both found an annual $\mathrm{Hg}$ export to the Arctic Ocean of about $20,000 \mathrm{~kg} \mathrm{yr}^{-1}$, of which $7,500 \mathrm{~kg} \mathrm{yr}^{-1} \quad\left(6,591 \mathrm{~kg} \mathrm{yr}^{-1}\right.$, respectively) are delivered by the Lena River. Furthermore, Lim et al. (2020) investigated a south to north transect in the Western Siberian lowlands and found that $\mathrm{Hg}$ concentrations in 
soil increased with latitude. Our findings confirm that. Thus it appears that those deposits with a higher $\mathrm{Hg}$ enrichment are also located closer to the oceanic ecosystem and also have a more direct impact on the oceanic ecosystem and thus further methylation processes.

To provide a rough risk assessment based on the findings in this study, we state the following: The amount of STHg found in this study is not alarmingly high (critical $\mathrm{Hg}$ concentration for contaminated soils is $1.5 \mathrm{mg} \mathrm{kg}^{-1}$ according to EU guidelines (Hein et al., 2011)). Still, we highlight that Arctic permafrost soils described in other studies contain more clay or more TOC (especially in relation to the TOC-poor Yukechi site) than our samples. Hence, we assume that higher $\mathrm{Hg}$ levels can be found in other permafrost regions of the Arctic with more TOC. Nevertheless, there is a natural background signal in the Arctic Ocean due to anthropogenic emissions coupled with exported $\mathrm{MeHg}$, and it will be biomagnified through food webs.

\section{CONCLUSION}

The sediment cores from Siberian permafrost deposits in this study contained $9.72 \pm 9.28 \mu \mathrm{g} \mathrm{STHg} \mathrm{kg}{ }^{-1}$ on average. Probably most of this STHg is inorganic $\mathrm{Hg}^{2+}$, but the formation of $\mathrm{CH}_{3} \mathrm{Hg}^{+}$after thawing or entering the Arctic Ocean is expected. The mean STHg concentration in the samples from the Yukechi study site is $5.21 \pm 3.66 \mu \mathrm{g} \mathrm{kg}^{-1}$, while the samples from the coastal area of Bykovsky contain nearly three times as much, namely $14.95 \pm 10.94 \mu \mathrm{g} \mathrm{kg}^{-1}$. The trend of STHg versus depth was quite similar in all four cores from the Yukechi Alas. The upper half of the cores showed decreasing concentrations, with the lowest STHg in the middle and a downward increase in the lower half. In contrast, all three cores from the Bykovsky Peninsula exhibited decreasing concentrations with depth, but with higher values in the near-surface layers. Therefore, at first glance the difference seems distinct between both study sites, but not between the single cores. However, our plots and statistics show that the varying deposition phases (mainly distinguished by age, location, and grain size distribution) lead to differences in STHg concentrations as well. According to our data, Holocene thermokarst and lagoonal deposits contain more STHg than late Pleistocene fluvial sands, while late Pleistocene Yedoma deposits consist partially of STHg similar to that found in Holocene alas deposits but with a lower average.

Moreover, we found a correlation of STHg with MS (negative) and clay content, TOC, and TN (all positive). Although the samples from Bykovsky contained coarser sediments in general, they were also less sorted and therefore partly contained a higher concentration of clay compared to the samples from Central Yakutia. Associated with the higher clay content, the $\mathrm{Hg}$ concentration was also higher in the cores from Bykovsky. The state of the investigated sections of the cores (whether originally frozen or not) was not obviously decisive for elemental enrichment or conservation.

Based on our study, the increasing thermokarst processes and coastal erosion in Arctic permafrost regions will liberate the available $\mathrm{Hg}$ and very likely enable the increase of highly toxic $\mathrm{CH}_{3} \mathrm{Hg}^{+}$in the terrestrial ecosystem, the Arctic Ocean, and the food chain. The amount of approximately $10 \mu \mathrm{g} \mathrm{Hg} \mathrm{kg}^{-1}$ in the studied Central Yakutian permafrost deposits is not expected to lead to immense and alarming injections of the metal pollutant $\mathrm{Hg}$ into the environment. Nonetheless, with regard to our $\mathrm{R}_{\mathrm{HgC}}$ and the TOC levels from other studies, we suggest the Yedoma $\mathrm{Hg}$ pool contains about $542 \mathrm{Gg}$, but this value comes with significant uncertainties. Other Arctic studies revealed more TOC and TN in sediments. Due to the positive correlation of these indicators with STHg, the circum-Arctic pool might be even larger as our findings suggest.

\section{DATA AVAILABILITY STATEMENT}

The original contributions presented in the study are included in the article/Supplementary Material, further inquiries can be directed to the corresponding author.

\section{AUTHOR CONTRIBUTIONS}

CR and JS designed the research and wrote the paper; CR performed research. JL, AL, JW and HL contributed towards ideas and data analysis and TR and SM contributed mercury analytics. JS, GG, MU, LS, AF, and MG participated in the expeditions to retrieve the cores. All co-authors commented on and contributed to the article.

\section{FUNDING}

This work is embedded into the CACOON project as a part of the Changing Arctic Ocean (CAO) program (\#03F0806A, German Federal Ministry of Education and Research, BMBF). CR was supported by the University of Salzburg ("Stipendium für kurzfristige wissenschaftliche Arbeiten”), JL was supported by the National Science Foundation (NSF Grant \#1500931), JW was supported by the German Research Foundation (DFG Research Grant No. WO 2420/2-1), GG was supported by the European Research Council (Starting Grant \#338335). MU was supported by the German Research Foundation (DFG Grant No.: UL426/1-1). AF was supported by the Russian Foundation for Basic Research (ID-No. 18-45-140046). The Nunataryuk project (EU H2020, \#773421) is acknowledged for fruitful discussion. We thank MPI Yakutsk for fieldwork assistance and UFZ Leipzig for their help with lab work. This work is part of the research focus "Permafrost BioGeoChemistry" at AWI Potsdam.

\section{SUPPLEMENTARY MATERIAL}

The Supplementary Material for this article can be found online at: https://www.frontiersin.org/articles/10.3389/feart.2021.718153/ full\#supplementary-material 


\section{REFERENCES}

Angelopoulos, M., Overduin, P. P., Westermann, S., Tronicke, J., Strauss, J., Schirrmeister, L., et al. (2020). Thermokarst Lake to Lagoon Transitions in Eastern Siberia: Do Submerged Taliks Refreeze? J. Geophys. Res. Earth Surf. 125 (10). doi:10.1029/2019jf005424

Barton, C., and Karathanasis, A. (2002). Clay Minerals Encyclopedia Of Soil Science. Marcel Dekker, Inc. AH rights reserved.

Beermann, F., Teltewskoi, A., Fiencke, C., Pfeiffer, E.-M., and Kutzbach, L. (2015). Stoichiometric Analysis of Nutrient Availability (N, P, K) within Soils of Polygonal Tundra. Biogeochemistry 122 (2), 211-227. doi:10.1007/s10533014-0037-4

Biskaborn, B. K., Smith, S. L., Noetzli, J., Matthes, H., Vieira, G., Streletskiy, D. A., et al. (2019). Permafrost Is Warming at a Global Scale. Nat. Commun. 10 (1), 264. doi:10.1038/s41467-018-08240-4

Blott, S. J., and Pye, K. (2001). GRADISTAT: a Grain Size Distribution and Statistics Package for the Analysis of Unconsolidated Sediments. Earth Surf. Process. Landforms 26 (11), 1237-1248. doi:10.1002/esp.261

Brouchkov, A., Fukuda, M., Fedorov, A., Konstantinov, P., and Iwahana, G. (2004). Thermokarst as a Short-Term Permafrost Disturbance, Central Yakutia. Permafrost Periglac. Process. 15 (1), 81-87. doi:10.1002/ppp.473

Burke, S. M., Zimmerman, C. E., Branfireun, B. A., Koch, J. C., and Swanson, H. K. (2017). Patterns and Controls of Mercury Accumulation in Sediments from Three Thermokarst Lakes on the Arctic Coastal Plain of Alaska. Aquat. Sci. 80 (1). doi:10.1007/s00027-017-0553-0

Carneado, S., Peró-Gascón, R., Ibáñez-Palomino, C., López-Sánchez, J. F., and Sahuquillo, A. (2015). Mercury(ii) and Methylmercury Determination in Water by Liquid Chromatography Hyphenated to Cold Vapour Atomic Fluorescence Spectrometry after Online Short-Column Preconcentration. Anal. Methods 7 (6), 2699-2706. doi:10.1039/c4ay02929a

Charbonnier, G., Adatte, T., Föllmi, K. B., and Suan, G. (2020). Effect of Intense Weathering and Postdepositional Degradation of Organic Matter on $\mathrm{Hg} / \mathrm{TOC}$ Proxy in Organic-rich Sediments and its Implicationsfor Deep-Time Investigations. Geochem. Geophys. Geosyst. 21 (2). doi: $10.1029 / 2019 \mathrm{gc} 008707$

Crate, S., Ulrich, M., Habeck, J. O., Desyatkin, A. R., Desyatkin, R. V., Fedorov, A. N., et al. (2017). Permafrost Livelihoods: A Transdisciplinary Review and Analysis of Thermokarst-Based Systems of Indigenous Land Use. Anthropocene 18, 89-104. doi:10.1016/j.ancene.2017.06.001

Douglas, T. A., and Blum, J. D. (2019). Mercury Isotopes Reveal Atmospheric Gaseous Mercury Deposition Directly to the Arctic Coastal Snowpack. Environ. Sci. Technol. Lett. 6 (4), 235-242. doi:10.1021/acs.estlett.9b00131

Douglas, T. A., Sturm, M., Simpson, W. R., Brooks, S., Lindberg, S. E., and Perovich, D. K. (2005). Elevated Mercury Measured in Snow and Frost Flowers Near Arctic Sea Ice Leads. Geophys. Res. Lett. 32 (4), a-n. doi:10.1029/2004GL022132

Driscoll, C. T., Mason, R. P., Chan, H. M., Jacob, D. J., and Pirrone, N. (2013). Mercury as a Global Pollutant: Sources, Pathways, and Effects. Environ. Sci. Technol. 47 (10), 4967-4983. doi:10.1021/es305071v

Duhaime, G., Chabot, M., Fréchette, P., Robichaud, V., and Proulx, S. (2004). The Impact of Dietary Changes Among the Inuit of Nunavik (Canada): a Socioeconomic Assessment of Possible Public Health Recommendations Dealing with Food Contamination. Risk Anal. 24 (4), 1007-1018. doi:10.1111/j.0272-4332.2004.00503.x

Faure, G. (1986). Principles of Isotope Geology. New York: Wiley.

Fedorov, A., and Konstantinov, P. (2003). "Observations of Surface Dynamics with Thermokarst Initiation, Yukechi Site, Central Yakutia," in Paper presented at the Proceedings of the 8th International Conference on Permafrost, Zurich, Switzerland, 21-25 July 2003.

Fedorov, A. N., Gavriliev, P. P., Konstantinov, P. Y., Hiyama, T., Iijima, Y., and Iwahana, G. (2014). Estimating the Water Balance of a Thermokarst lake in the Middle of the Lena River basin, Eastern Siberia. Ecohydrol. 7 (2), 188-196. doi:10.1002/eco.1378

Folk, R. L., and Ward, W. C. (1957). Brazos River Bar [Texas]; a Study in the Significance of Grain Size Parameters. J. Sediment. Res. 27 (1), 3-26. doi:10.1306/74d70646-2b21-11d7-8648000102c1865d
Frohne, T., Rinklebe, J., Langer, U., Du Laing, G., Mothes, S., and Wennrich, R. (2012). Biogeochemical Factors Affecting Mercury Methylation Rate in Two Contaminated Floodplain Soils. Biogeosciences 9 (1), 493-507. doi:10.5194/bg9-493-2012

Fuchs, M., Nitze, I., Strauss, J., Günther, F., Wetterich, S., Kizyakov, A., et al. (2020). Rapid Fluvio-Thermal Erosion of a Yedoma Permafrost Cliff in the Lena River Delta. Front. Earth Sci. 8. doi:10.3389/feart.2020.00336

Giesler, R., Clemmensen, K. E., Wardle, D. A., Klaminder, J., and Bindler, R. (2017). Boreal Forests Sequester Large Amounts of Mercury over Millennial Time Scales in the Absence of Wildfire. Environ. Sci. Technol. 51 (5), 2621-2627. doi:10.1021/acs.est.6b06369

Glückler, R., Herzschuh, U., Kruse, S., Andreev, A., Vyse, S. A., Winkler, B., et al. (2021). Wildfire History of the Boreal forest of South-Western Yakutia (Siberia) over the Last Two Millennia Documented by a lake-sediment Charcoal Record. Biogeosciences 18, 4185-4209. doi:10.5194/bg-18-4185-2021

Grosse, G., Robinson, J., Bryant, R., Taylor, M., Harper, W., DeMasi, A., et al. (2013). Distribution of Late Pleistocene Ice-Rich Syngenetic Permafrost of the Yedoma Suite in East and Central Siberia. Russia.

Grosse, G., Schirrmeister, L., Kunitsky, V. V., and Hubberten, H.-W. (2005). The Use of CORONA Images in Remote Sensing of Periglacial Geomorphology: an Illustration from the NE Siberian Coast. Permafrost Periglac. Process. 16 (2), 163-172. doi:10.1002/ppp.509

Ha, E., Basu, N., Bose-O'Reilly, S., Dórea, J. G., McSorley, E., Sakamoto, M., et al. (2017). Current Progress on Understanding the Impact of Mercury on Human Health. Environ. Res. 152, 419-433. doi:10.1016/j.envres.2016.06.042

Hein, H., Klaus, S., Meyer, A., and Schwedt, G. (2011). Richt- und Grenzwerte im deutschen und europäischen Umweltrecht: Wasser - Boden - Abfall - Gefahrstoffe - Luft - Lärm. Düsseldorf: Springer-VDI-Verlag GmbH \& Co. KG.

Jenrich, M., Angelopoulos, M., Grosse, G., Overduin, P. P., Schirrmeister, L., Nitze, I., et al. (2021). Thermokarst Lagoons: A Core-Based Assessment of Depositional Characteristics and Estimate of Carbon Pools on Bykovsky Peninsula. Front. Earth Sci. 9. doi:10.3389/feart.2021.637899

Jiskra, M., Sonke, J. E., Agnan, Y., Helmig, D., and Obrist, D. (2019). Insights from Mercury Stable Isotopes on Terrestrial-Atmosphere Exchange of $\mathrm{Hg}(0)$ in the Arctic Tundra. Biogeosciences 16 (20), 4051-4064. doi:10.5194/bg-16-4051-2019

Jones, B. M., Irrgang, A. M., Farquharson, L. M., Lantuit, H., Whalen, D., Ogorodov, S., et al. (2020). "Coastal Permafrost Erosion," in Arctic Report Card 2020. Editors R. L. Thoman, J. Richter-Menge, and M. L. Druckenmiller.

Jongejans, L. L., Liebner, S., Knoblauch, C., Mangelsdorf, K., Ulrich, M., Grosse, G., et al. (2021). Greenhouse Gas Production and Lipid Biomarker Distribution in Yedoma and Alas Thermokarst lake Sediments in Eastern Siberia. Glob. Change Biol. doi:10.1111/gcb.15566

Jongejans, L. L., Mangelsdorf, K., Schirrmeister, L., Grigoriev, M. N., Maksimov, G. M., Biskaborn, B. K., et al. (2020). n-Alkane Characteristics of Thawed Permafrost Deposits below a Thermokarst Lake on Bykovsky Peninsula, Northeastern Siberia. Front. Environ. Sci. 8. doi:10.3389/fenvs.2020.00118

Kanevskiy, M., Shur, Y., Strauss, J., Jorgenson, T., Fortier, D., Stephani, E., et al. (2016). Patterns and Rates of riverbank Erosion Involving Ice-Rich Permafrost (Yedoma) in Northern Alaska. Geomorphology 253, 370-384. doi:10.1016/ j.geomorph.2015.10.023

Katamura, F., Fukuda, M., Bosikov, N. P., and Desyatkin, R. V. (2009). Forest Fires and Vegetation during the Holocene in central Yakutia, Eastern Siberia. J. For. Res. 14 (1), 30-36. doi:10.1007/s10310-008-0099-z

Kostyukevich, V. V. (1993). A Regional Geochronological Study of Late Pleistocene Permafrost. Radiocarbon 35 (3), 477-486. doi:10.1017/s0033822200060501

Lantuit, H., Atkinson, D., Paul Overduin, P., Grigoriev, M., Rachold, V., Grosse, G., et al. (2011). Coastal Erosion Dynamics on the Permafrost-Dominated Bykovsky Peninsula, north Siberia, 1951-2006. Polar Res. 30 (1), 7341. doi:10.3402/ polar.v30i0.7341

Larsen, J. N., Anisimov, O. A., Constable, A., Hollowed, A. B., Maynard, N., Prestrud, P., et al. (2014). Polar Regions. New York, USA: Retrieved from CambridgeU.K.

Lehnherr, I., St. Louis, V. L., Hintelmann, H., and Kirk, J. L. (2011). Methylation of Inorganic Mercury in Polar marine Waters. Nat. Geosci 4 (5), 298-302. doi:10.1038/ngeo1134

Lenz, J., Fritz, M., Schirrmeister, L., Lantuit, H., Wooller, M. J., Pollard, W. H., et al. (2013). Periglacial Landscape Dynamics in the Western Canadian Arctic: Results from a Thermokarst lake Record on a Push Moraine (Herschel 
Island, Yukon Territory). Palaeogeogr. Palaeoclimatol. Palaeoecol. 381-382, 15-25. doi:10.1016/j.palaeo.2013.04.009

Lim, A. G., Jiskra, M., Sonke, J. E., Loiko, S. V., Kosykh, N., and Pokrovsky, O. S. (2020). A Revised Pan-Arctic Permafrost Soil Hg Pool Based on Western Siberian Peat Hg and Carbon Observations. Biogeosciences 17 (12), 3083-3097. doi:10.5194/bg-17-3083-2020

Lim, A. G., Sonke, J. E., Krickov, I. V., Manasypov, R. M., Loiko, S. V., and Pokrovsky, O. S. (2019). Enhanced Particulate Hg export at the Permafrost Boundary, Western Siberia. Environ. Pollut. 254 (Pt B), 113083. doi:10.1016/ j.envpol.2019.113083

Lindgren, A., Hugelius, G., and Kuhry, P. (2018). Extensive Loss of Past Permafrost Carbon but a Net Accumulation into Present-Day Soils. Nature 560 (7717), 219-222. doi:10.1038/s41586-018-0371-0

MacMillan, G. A., Girard, C., Chételat, J., Laurion, I., and Amyot, M. (2015). High Methylmercury in Arctic and Subarctic Ponds Is Related to Nutrient Levels in the Warming Eastern Canadian Arctic. Environ. Sci. Technol. 49 (13), 7743-7753. doi:10.1021/acs.est.5b00763

Martin, J.-M., and Meybeck, M. (1979). Elemental Mass-Balance of Material Carried by Major World Rivers. Mar. Chem. 7 (3), 173-206. doi:10.1016/ 0304-4203(79)90039-2

M., H., and R., S. (2002). Mapping of Heavy Metal Loadings in Soils by Means of Magnetic Susceptibility Measurements. Environ. Geology. 42 (8), 857-870. doi:10.1007/s00254-002-0604-1

Mu, C., Zhang, F., Chen, X., Ge, S., Mu, M., Jia, L., et al. (2019). Carbon and Mercury export from the Arctic Rivers and Response to Permafrost Degradation. Water Res. 161, 54-60. doi:10.1016/j.watres.2019.05.082

Mullins, C. E. (1977). Magnetic Susceptibility of the Soil and its Significance in Soil Science - a Review. J. Soil Sci. 28 (2), 223-246. doi:10.1111/j.13652389.1977.tb02232.x

Munthe, J., Wängberg, I., Rognerud, S., Fjeld, E., Verta, M., Porvari, P., et al. (2007). Mercury in Nordic Ecosystems.

Mwamburi, J. (2003). Variations in Trace Elements in Bottom Sediments of Major Rivers in Lake Victoria's basin, Kenya. Lakes Reserv Res. Manage. 8 (1), 5-13. doi:10.1046/j.1440-1770.2003.00212.x

Nachar, N. (2008). The Mann-Whitney U: A Test for Assessing whether Two Independent Samples Come from the Same Distribution. Tqmp 4 (1), 13-20. doi:10.20982/tqmp.04.1.p013

Nitze, I., Grosse, G., Jones, B. M., Romanovsky, V. E., and Boike, J. (2018). Remote Sensing Quantifies Widespread Abundance of Permafrost Region Disturbances across the Arctic and Subarctic. Nat. Commun. 9, 5423. doi:10.1038/s41467018-07663-3

Nowack, B., and VanBriesen, J. M. (2005). "Chelating Agents in the Environment," in Biogeochemistry of Chelating Agents. Editors B. Nowack and J. M. VanBriesen (Washington, DC: ACS Publications). doi:10.1021/bk2005-0910.ch001

Obrist, D., Agnan, Y., Jiskra, M., Olson, C. L., Colegrove, D. P., Hueber, J., et al. (2017). Tundra Uptake of Atmospheric Elemental Mercury Drives Arctic Mercury Pollution. Nature 547 (7662), 201-204. doi:10.1038/nature22997

Obrist, D., Johnson, D. W., and Lindberg, S. E. (2009). Mercury Concentrations and Pools in Four Sierra Nevada forest Sites, and Relationships to Organic Carbon and Nitrogen. Biogeosciences 6 (5), 765-777. doi:10.5194/bg-6-7652009

Olson, C. L., Jiskra, M., Sonke, J. E., and Obrist, D. (2019). Mercury in Tundra Vegetation of Alaska: Spatial and Temporal Dynamics and Stable Isotope Patterns. Sci. total Environ. 660, 1502-1512. doi:10.1016/j.scitotenv.2019.01.058

Overduin, P. P., Wetterich, S., Günther, F., Grigoriev, M. N., Grosse, G., Schirrmeister, L., et al. (2016). Coastal Dynamics and Submarine Permafrost in Shallow Water of the central Laptev Sea, East Siberia. The Cryosphere 10 (4), 1449-1462. doi:10.5194/tc-10-1449-2016

Pirrone, N., Cinnirella, S., Feng, X., Finkelman, R. B., Friedli, H. R., Leaner, J., et al. (2009). "Global Mercury Emissions to the Atmosphere from Natural and Anthropogenic Sources," in Mercury Fate and Transport in the Global Atmosphere: Emissions, Measurements and Models. Editors R. Mason and N. Pirrone (Boston, MA: Springer US), 1-47. doi:10.1007/978-0-387-93958-2_1

Ramage, J., Jungsberg, L., Wang, S., Westermann, S., Lantuit, H., and Heleniak, T. (2021). Population Living on Permafrost in the Arctic. Popul. Environ. 43, 22-38. doi:10.1007/s11111-020-00370-6
Ravichandran, M. (2004). Interactions between Mercury and Dissolved Organic Matter-Aa Review. Chemosphere 55 (3), 319-331. doi:10.1016/ j.chemosphere.2003.11.011

RStudio Team (2020). RStudio. Boston, MA: Integrated Development for R. RStudio, PBC. Availableat: http://www.rstudio.com/.

Rydberg, J., Klaminder, J., Rosén, P., and Bindler, R. (2010). Climate Driven Release of Carbon and Mercury from Permafrost Mires Increases Mercury Loading to Sub-arctic Lakes. Sci. Total Environ. 408 (20), 4778-4783. doi:10.1016/ j.scitotenv.2010.06.056

Sanei, H., Grasby, S. E., and Beauchamp, B. (2012). Latest Permian Mercury Anomalies. Geology 40 (1), 63-66. doi:10.1130/g32596.1

Schaefer, K., Elshorbany, Y., Jafarov, E., Schuster, P. F., Striegl, R. G., Wickland, K. P., et al. (2020). Potential Impacts of Mercury Released from Thawing Permafrost. Nat. Commun. 11 (1), 4650. doi:10.1038/s41467-020-18398-5

Schirrmeister, L., Dietze, E., Matthes, H., Grosse, G., Strauss, J., Laboor, S., et al. (2020). The Genesis of Yedoma Ice Complex Permafrost - Grain-Size Endmember Modeling Analysis from Siberia and Alaska. E\&g Quat. Sci. J. 69 (1), 33-53. doi:10.5194/egqsj-69-33-2020

Schirrmeister, L., Froese, D., Tumskoy, V., Grosse, G., and Wetterich, S. (2013). PERMAFROST and PERIGLACIAL FEATURES |. Yedoma: Late Pleistocene Ice-Rich Syngenetic Permafrost of Beringia, 542-552. doi:10.1016/b978-0-44453643-3.00106-0

Schirrmeister, L., Grigoriev, M. N., Strauss, J., Grosse, G., Overduin, P. P., Kholodov, A., et al. (2018). Sediment Characteristics of a Thermokarst Lagoon in the Northeastern Siberian Arctic (Ivashkina Lagoon, Bykovsky Peninsula). arktos 4 (1), 1-16. doi:10.1007/s41063-018-0049-8

Schirrmeister, L., Kunitsky, V., Grosse, G., Wetterich, S., Meyer, H., Schwamborn, G., et al. (2011). Sedimentary Characteristics and Origin of the Late Pleistocene Ice Complex on north-east Siberian Arctic Coastal Lowlands and Islands-A Review. Quat. Int. 241 (1-2), 3-25. doi:10.1016/j.quaint.2010.04.004

Schirrmeister, L., Siegert, C., Kuznetsova, T., Kuzmina, S., Andreev, A., Kienast, F., et al. (2002). Paleoenvironmental and Paleoclimatic Records from Permafrost Deposits in the Arctic Region of Northern Siberia. Quat. Int. 89 (1), 97-118. doi:10.1016/s1040-6182(01)00083-0

Schmidt, A., Yarnold, R., Hill, M., and Ashmore, M. (2005). Magnetic Susceptibility as Proxy for Heavy Metal Pollution: a Site Study. J. Geochemical Exploration 85 (3), 109-117. doi:10.1016/j.gexplo.2004.12.001

Schneider, J., Grosse, G., and Wagner, D. (2009). Land Cover Classification of Tundra Environments in the Arctic Lena Delta Based on Landsat 7 ETM+ Data and its Application for Upscaling of Methane Emissions. Remote Sensing Environ. 113 (2), 380-391. doi:10.1016/j.rse.2008.10.013

Schroeder, W. H., and Munthe, J. (1998). Atmospheric Mercury-An Overview. Atmos. Environ. 32 (5), 809-822. doi:10.1016/S1352-2310(97)00293-8

Schuster, P. F., Schaefer, K. M., Aiken, G. R., Antweiler, R. C., Dewild, J. F., Gryziec, J. D., et al. (2018). Permafrost Stores a Globally Significant Amount of Mercury. Geophys. Res. Lett. 45 (3), 1463-1471. doi:10.1002/2017gl075571

Schuster, P. F., Striegl, R. G., Aiken, G. R., Krabbenhoft, D. P., Dewild, J. F., Butler, K., et al. (2011). Mercury export from the Yukon River Basin and Potential Response to a Changing Climate. Environ. Sci. Technol. 45 (21), 9262-9267. doi:10.1021/es202068b

Schuur, E. A. G., Bockheim, J., Canadell, J. G., Euskirchen, E., Field, C. B., Goryachkin, S. V., et al. (2008). Vulnerability of Permafrost Carbon to Climate Change: Implications for the Global Carbon Cycle. BioScience 58 (8), 701-714. doi:10.1641/b580807

Schuur, E. A. G., McGuire, A. D., Schädel, C., Grosse, G., Harden, J. W., Hayes, D. J., et al. (2015). Climate Change and the Permafrost Carbon Feedback. Nature 520 (7546), 171-179. doi:10.1038/nature14338

Skyllberg, U., Bloom, P. R., Qian, J., Lin, C.-M., and Bleam, W. F. (2006). Complexation of Mercury (II) In Soil Organic Matter: EXAFS Evidence For Linear Two-Coordination With Reduced Sulfur Groups. Environ. Sci. Technol., 40 (13), 4174-4180.

Smith-Downey, N. V., Sunderland, E. M., and Jacob, D. J. (2010). Anthropogenic Impacts on Global Storage and Emissions of Mercury from Terrestrial Soils: Insights from a New Global Model. J. Geophys. Res. 115 (G3). doi:10.1029/ 2009jg001124

Soerensen, A. L., Jacob, D. J., Schartup, A. T., Fisher, J. A., Lehnherr, I., St. Louis, V. L. V. L., et al. (2016). A Mass Budget for Mercury and Methylmercury in the 
Arctic Ocean. Glob. Biogeochem. Cycles 30 (4), 560-575. doi:10.1002/ 2015gb005280

Sohalscha, E. B., Appelt, H., and Schatz, A. (1967). Chelation as a Weathering Mechanism-I. Effect of Complexing Agents on the Solubilization of Iron from Minerals and Granodiorite. Geochimica et Cosmochimica Acta 31 (4), 587-596. doi:10.1016/0016-7037(67)90035-X

Soloviev, P. A. (1973). Thermokarst Phenomena and Landforms Due to Frostheaving in Central Yakutia. Biuletyn Peryglacjalny 23, 135-155.

Sonke, J. E., Teisserenc, R., Heimbürger-Boavida, L.-E., Petrova, M. V., Marusczak, N., Le Dantec, T., et al. (2018). Eurasian River spring Flood Observations Support Net Arctic Ocean Mercury export to the Atmosphere and Atlantic Ocean. Proc. Natl. Acad. Sci. USA 115 (50), E11586-E11594. doi:10.1073/ pnas. 1811957115

Steffen, A., Douglas, T., Amyot, M., Ariya, P., Aspmo, K., Berg, T., et al. (2008). A Synthesis of Atmospheric Mercury Depletion Event Chemistry in the Atmosphere and Snow. Atmos. Chem. Phys. 8 (6), 1445-1482. doi:10.5194/ acp-8-1445-2008

Stern, G. A., Macdonald, R. W., Outridge, P. M., Wilson, S., Chételat, J., Cole, A., et al. (2012). How Does Climate Change Influence Arctic Mercury? Sci. Total Environ. 414, 22-42. doi:10.1016/j.scitotenv.2011.10.039

St. Pierre, K. A., St. Louis, V. L., Lehnherr, I., Wang, S., La Farge, C., et al. (2015). Importance of Open Marine Waters to the Enrichment of Total Mercury and Monomethylmercury in Lichens in the Canadian High Arctic. Environ. Sci. Technol. 49 (10), 5930-5938. doi:10.1021/ acs.est.5b00347

St. Pierre, K. A., Zolkos, S., Shakil, S., Tank, S. E., St. Louis, V. L. V. L., and Kokelj, S. V. (2018). Unprecedented Increases in Total and Methyl Mercury Concentrations Downstream of Retrogressive Thaw Slumps in the Western Canadian Arctic. Environ. Sci. Technol. 52 (24), 14099-14109. doi:10.1021/ acs.est.8b05348

Strauss, J., Grigoriev, M., Maximov, G., Pravkin, S., and Schirrmeister, L. (2018). Drilling Campaign on Bykovsky Peninsula: Spring 2017.

Strauss, J., Schirrmeister, L., Grosse, G., Fortier, D., Hugelius, G., Knoblauch, C., et al. (2017). Deep Yedoma Permafrost: A Synthesis of Depositional Characteristics and Carbon Vulnerability. Earth-Science Rev. 172, 75-86. doi:10.1016/j.earscirev.2017.07.007

Strauss, J., Schirrmeister, L., Grosse, G., Wetterich, S., Ulrich, M., Herzschuh, U., et al. (2013). The Deep Permafrost Carbon Pool of the Yedoma Region in Siberia and Alaska. Geophys. Res. Lett. 40 (23), 6165-6170. doi:10.1002/ 2013GL058088

Strauss, J., Schirrmeister, L., Wetterich, S., Borchers, A., and Davydov, S. P. (2012). Grain-size Properties and Organic-carbon Stock of Yedoma Ice Complex Permafrost from the Kolyma lowland, Northeastern Siberia. Glob. Biogeochem. Cycles 26 (3). doi:10.1029/2011gb004104

Streets, D. G., Devane, M. K., Lu, Z., Bond, T. C., Sunderland, E. M., and Jacob, D. J. (2011). All-time Releases of Mercury to the Atmosphere from Human Activities. Environ. Sci. Technol. 45 (24), 10485-10491. doi:10.1021/ es $202765 \mathrm{~m}$

Tipping, E. (2002). Cation Binding by Humic Substances, Vol. 12. Cambridge University Press.

Ulrich, M., Jongejans, L. L., Grosse, G., Schneider, B., Opel, T., Wetterich, S., et al. (2021). Geochemistry and Weathering Indices of Yedoma and Alas Deposits beneath Thermokarst Lakes in Central Yakutia. Front. Earth Sci. 9. doi:10.3389/ feart.2021.704141
Ullrich, S. M., Tanton, T. W., and Abdrashitova, S. A. (2001). Mercury in The Aquatic Environment: A Review of Factors Affecting Methylation. Crit. Rev. Environ. Sci. Technol., 31 (3), 241-293.

Ulrich, M., Matthes, H., Schirrmeister, L., Schütze, J., Park, H., Iijima, Y., et al. (2017). Differences in Behavior and Distribution of Permafrost-related Lakes in C Entral Y Akutia and Their Response to Climatic Drivers. Water Resour. Res. 53 (2), 1167-1188. doi:10.1002/2016wr019267

Ulrich, M., Matthes, H., Schmidt, J., Fedorov, A. N., Schirrmeister, L., Siegert, C., et al. (2019). Holocene Thermokarst Dynamics in Central Yakutia - A MultiCore and Robust Grain-Size Endmember Modeling Approach. Quat. Sci. Rev. 218, 10-33. doi:10.1016/j.quascirev.2019.06.010

Walz, J., Knoblauch, C., Tigges, R., Opel, T., Schirrmeister, L., and Pfeiffer, E.-M. (2018). Greenhouse Gas Production in Degrading Ice-Rich Permafrost Deposits in Northeastern Siberia. Biogeosciences 15 (17), 5423-5436. doi:10.5194/bg-15-5423-2018

Wang, X. S., and Qin, Y. (2005). Correlation between Magnetic Susceptibility and Heavy Metals in Urban Topsoil: a Case Study from the City of Xuzhou, China. Environ. Geol. 49 (1), 10-18. doi:10.1007/s00254-005-0015-1

Whitney, P. R. (1975). Relationship of Manganese-Iron Oxides and Associated Heavy Metals to Grain Size in Stream Sediments. J. Geochemical Exploration 4 (2), 251-263. doi:10.1016/0375-6742(75)90005-9

Windirsch, T., Grosse, G., Ulrich, M., Schirrmeister, L., Fedorov, A. N., Konstantinov, P. Y., et al. (2020). Organic Carbon Characteristics in IceRich Permafrost in Alas and Yedoma Deposits, central Yakutia, Siberia. Biogeosciences 17 (14), 3797-3814. doi:10.5194/bg-17-3797-2020

Xin, M., Gustin, M., and Johnson, D. (2007). Laboratory Investigation of the Potential for Re-emission of Atmospherically Derived $\mathrm{Hg}$ from Soils. Environ. Sci. Technol. 41 (14), 4946-4951. doi:10.1021/es062783f

Zar, J. H. (2005). Spearman Rank Correlation Encyclopedia Of Biostatistics.

Zolkos, S., Krabbenhoft, D. P., Suslova, A., Tank, S. E., McClelland, J. W., Spencer, R. G. M., et al. (2020). Mercury export from Arctic Great Rivers. Environ. Sci. Technol. 54 (7), 4140-4148. doi:10.1021/acs.est.9b07145

Zonta, R., Zaggia, L., and Argese, E. (1994). Heavy Metal and Grain-Size Distributions in Estuarine Shallow Water Sediments of the Cona Marsh (Venice Lagoon, Italy), 151(1), 19-28.

Conflict of Interest: The authors declare that the research was conducted in the absence of any commercial or financial relationships that could be construed as a potential conflict of interest.

Publisher's Note: All claims expressed in this article are solely those of the authors and do not necessarily represent those of their affiliated organizations, or those of the publisher, the editors and the reviewers. Any product that may be evaluated in this article, or claim that may be made by its manufacturer, is not guaranteed or endorsed by the publisher.

Copyright (๑) 2021 Rutkowski, Lenz, Lang, Wolter, Mothes, Reemtsma, Grosse, Ulrich, Fuchs, Schirrmeister, Fedorov, Grigoriev, Lantuit and Strauss. This is an open-access article distributed under the terms of the Creative Commons Attribution License (CC BY). The use, distribution or reproduction in other forums is permitted, provided the original author(s) and the copyright owner(s) are credited and that the original publication in this journal is cited, in accordance with accepted academic practice. No use, distribution or reproduction is permitted which does not comply with these terms. 